\title{
Strategies to Maximize the Wood Production in Amazon Forest
}

\author{
Aline Canetti \\ Independent forest consultant \\ Evaldo Muñoz Braz \\ Embrapa Florestas \\ Patricia Mattos ( $\nabla$ patricia.mattos@embrapa.br) \\ Embrapa Florestas https://orcid.org/0000-0003-4134-8890 \\ Renato Olivir Basso \\ Elabore Projetos e Consultoria Florestal \\ Afonso Figueiredo Filho \\ UNICENTRO: Universidade Estadual do Centro-Oeste
}

\section{Research}

Keywords: dendrochronology, forest modeling, minimum cutting diameter

Posted Date: October 1st, 2020

DOI: https://doi.org/10.21203/rs.3.rs-83620/v1

License: (c) (1) This work is licensed under a Creative Commons Attribution 4.0 International License. Read Full License 


\section{TITLE PAGE}

\section{Strategies to maximize the wood production in Amazon forest}

Aline Canetti ${ }^{1}$, Evaldo Muñoz Braz ${ }^{2}$, Patrícia Póvoa de Mattos ${ }^{2 *}$, Renato Olivir Basso ${ }^{3}$, Afonso Figueiredo Filho ${ }^{4}$

(Canetti, A., Braz, E. M., Mattos, P. P., Basso, R. O., Figueiredo Filho, A.)

*Corresponding author: patricia.mattos@embrapa.br, +55 41 3675-5625 fax: +55 41

$3675-5600$

${ }^{1}$ Independent forestry consultant; E-mail: alinecanetti@gmail.com

${ }^{2}$ Embrapa Florestas. Estrada da Ribeira Km 111, Caixa Postal 319. 83411-000,

Colombo, PR, Brazil; E-mail: evaldo.braz@embrapa.br; patricia.mattos@embrapa.br

${ }^{3}$ Elabore Projetos e Consultoria Florestal. Av. Gov. Júlio Campos, 207 - St. Comercial.

78550-000, Sinop, Brazil; E-mail: elabore@terra.com.br

${ }^{4}$ Universidade Estadual do Centro-Oeste. PR 153, Km 7, s/n - Riozinho, Irati, PR,

Brazil.84500-000.E-mail: afigfilho@gmail.com

\section{To the Editor-in-Chief:}

Dear Sir,

We would like to submit the manuscript "Strategies to maximize the wood production in Amazon forest" to possible publication in the Forest Ecosystems Journal, we strongly believe our theme fits within its scope.

We confirm that the manuscript was not published or it is not under evaluation elsewhere in substantially the same or abbreviated form, either in print or electronically. The innovation of this paper was the use of the analysis of the original structure of the forest combined with growth models to predict the optimal wood production in Amazon forest. It may be used by forest managers and forest law-makers, aiming to maximize sustainable wood production in the Amazon Forest.

Forest Ecology and Management was the most cited journal in our paper and

Sincerelly,

Patrícia Póvoa de Mattos 


\section{Strategies to maximize the wood production in Amazon forest}

3 ABSTRACT

4 Background: This study aimed to develop a procedure to determine which logging

5 diameter would achieve optimal wood production by species, aiming to support

6 sustainable management of the Amazon forest. Two main methodologies of analysis by

7 species were combined: probability density function (PDF) and growth modeling. The

8 growth models were used to derive the volume increment curves at the individual tree

9 level. To detect the points of maximum annual increment in volume at the population

10 tree level we used PDF with adjusted growth equations.

11 Results: The population maximum annual volumetric increments occurred in smaller

12 diameters compared to that of the individual-level. When combining shorter cutting

13 cycles with the population biological rotation point considered as the minimum cutting

14 diameter (MCD), we observed higher annual increments in volume than that achieved

15 using the Brazilian law criteria $(\mathrm{MCD}=50 \mathrm{~cm})$ or other $\mathrm{MCD}$ tested.

16 Conclusion: The procedure proposed may be used by forest managers and forest law-

17 makers, aiming to maximize sustainable wood production in the Amazon forest.

18 Keywords: dendrochronology; forest modeling; minimum cutting diameter

\section{Background}

21 Natural forests are steadily accumulating biomass, reflected in the production of carbon

22 and wood. The forest functions must be maintained after logging, and the remaining stocks must allow a continuous production of wood for the next interventions, ensuring

24 forest management sustainability (Ong; Kleine, 1996; Van Gardingen et al., 2006; Braz

25 et al., 2015; Avila et al., 2017). The management must be carefully planned and be 
consistent with the initial natural forest structure (e.g., density, diametric distribution,

27 growth, mortality, and regeneration) of the species of interest (Seydack et al., 1995;

28 Bick et al., 1998).

29 According to Seydack (2012), a challenge for forestry scientists is to combine modeling

30 and simulation tools to understand tropical forest dynamics, enabling production

31 maximization. Minimum cutting diameters (MCD) should be defined for all commercial

32 species, representing a powerful tool in maximizing increment for tropical forests under

33 management as in the Amazon region.

34 Knowledge of the natural forest balance allows identification of the ideal moment of 35 intervention and its production potential (Bick et al., 1998). The forest balance equation 36 depends on how tree increment occurs over time. Studies of species growth at 37 individual-level, structure, and reproductive biology are the basis for defining the management guidelines that guarantee sustainability for wood production in tropical forests (Vanclay, 1989; Miranda, D. L. C. et al., 2018; Dionisio et al., 2018).

Forest growth goes through youth, maturity, senescence, and stagnation phases. Its basic

41 unit is the tree, which has a distinct sigmoidal growth pattern, tending to a biological 42 limit (Odum, 1988). Trees that were established decades ago will grow within the ingress criteria for classes with larger diameters, will stagnate or eventually die. Thus, a diametric distribution of natural forest is the result of several tree establishments over different periods.

46 Diametric distribution is a useful factor to describe the forest properties since the 47 diameter is easily obtained and correlated with other variables such as volume, which defines the economic value of the forest area (Bailey; Dell, 1973). Diameter is widely used in the forest sector to assess the effect of environmental and anthropogenic disturbances (Kohyama, 1986; Coomes et al., 2003; Wright et al., 2003; Bettinger et al., 
2009; Hossain et al., 2015), to describe successional patterns (Kohyama, 1986; Wright et al., 2003; Wang et al., 2009) and for the prediction of the future stock of a stand (De Liocourt, 1898; Meyer, 1952; Carvalho, 1981; Condit et al. , 1998; Bettinger et al., 2009; Hossain et al., 2015; Orellana; Figueiredo Filho, 2017). However, future stock projection is difficult for tropical forest due to its great diversity (Orellana, Figueiredo Filho, 2017). Moreover, information about individual species distribution pattern is scarce.

Describing forest growth trajectory requires long-term information when permanent plots are used as data source (Bick et al., 1998). The successive measurements can make it difficult or even imply a failed simulation, due to the time spent to replicate a structure that represents the initial diametric classes up to the biological diameter limit of the species (Brienen; Zuidema, 2006a; Miranda D. L. C. et al., 2018).

Most studies of the species forest growth in the Amazon basin were carried out with permanent plots (Silva, 1989; 1997; Higuchi, 1996; Fortini et al., 2015; Avila et al., 2017; D'Oliveira et al., 2017) and supported the management guidelines in the Brazilian legislation (Silva, 1989, 1997; Higuchi, 1996). However, in some species less than one individual per hectare occurs in Amazonian primary forest structure, especially when considering trees with commercial dimensions (Miranda, D. L. C. et al., 2018), and extensive sample areas are therefore required to properly represent a population of individual species (Groenendijk et al., 2017; Miranda, D. L. C. et al., 2018.).

In addition to area size, time scale is also a limiting factor in studying forest dynamics with permanent plots (Brienen; Zuidema, 2006a; Miranda, D. L. C. et al., 2018). In Brazil, permanent plots monitored for more than 40 years are rare. These periods are short compared to the age of commercial trees, which are rarely less than 100 years old (Brienen; Zuidema, 2006a; Schöngart, 2008; Rosa et al., 2017). 
76 Growth series obtained by dendrochronology became more popular as an alternative to

77 permanent-plot data to supply the demand for information and growth models of species

78 (Brienen, 2005; Brienen; Zuidema, 2006a; Schöngart, 2011; Mattos et al., 2015; Canetti

et al., 2017; Groenendijk et al., 2017; Miranda, D. L. C. et al., 2018). Growth ring

80 analysis is a fast and reliable tool for assessing tree age, determining its growth rates

81 over the life cycle, and identifying growth differences between species (Groenendijk et

82 al., 2017; Rosa et al., 2017).

83 This study aimed to develop a procedure based on the diametric structure and growth models to set the minimum cutting diameter (MCD) for optimal wood production. The procedure was tested on four species in the Brazilian Amazon. The results may be used as a basis for forest management plans and to aid in the revision and modernization of

87 forest law in countries with humid tropical forests.

\section{Methods}

This study was conducted in the Sinop micro-region (11 $\left.{ }^{\circ} 50 \mathrm{~S} ; 54^{\circ} 50^{\prime} \mathrm{W}\right)$, Mato Grosso (MT) state, within the Brazilian Legal Amazon. The region comprises 9 municipalities, encompassing nearly 40 thousand $\mathrm{km}^{2}$ (IBGE, 2010). The region's vegetation is characterized by a transition zone between open tropical rainforest and deciduous tropical rainforest, and is the largest area composed of this ecotone in the world (IBGE 1992; SIVAM 2002). The micro-region presents flat relief and tropical climate with a dry season between autumn and winter (Alvares et al., 2013). All compartments from

97 which data were collected were included in sustainable forest management plans authorized by the State Environmental Agency (SEMA-MT).

99 The species Apuleia leiocarpa (Vogel) J.F. Macbr., Erisma uncinatum Warm., 
101 Together, these species represent $25 \%$ of the commercial volume logged in the micro-

102 region of Sinop, the second-largest tropical wood production hub in Brazil (Ribeiro et 103 al., 2016).

\section{Fitting probability density function of the diametric structure of species}

105 The data were obtained from $100 \%$ inventories of six forest compartments carried out in

106 the municipalities of Santa Carmem, Sinop, and União do Sul, totaling 5,432 ha. Forest

107 inventories were conducted from 2011 to 2014, by measuring all trees with diameter at $1081.30 \mathrm{~m}$ above ground level $(\mathrm{dbh}) \geq 40 \mathrm{~cm}(\mathrm{n}=3,617$ for A. leiocarpa, 13,655 for E.

109 uncinatum, 1,814 for H. excelsum, and 16,162 for T. burserifolia).

110 Data from sample units of 0.25 ha $(10 \mathrm{~m} \times 250 \mathrm{~m})$ were also used to complement the

111 densities of the smaller diameter trees $(20 \leq \mathrm{dbh} \leq 40 \mathrm{~cm})$, not covered in the $100 \%$

112 inventories. These plots were measured in four compartments in the municipalities of

113 Santa Carmem and Feliz Natal, MT. All trees with dbh $\geq 20 \mathrm{~cm}$ were measured.

114 Altogether, data from 138 plots were used, adding up to 36 ha inventoried. On average,

115 there were 35 trees $\mathrm{ha}^{-1}$ with $20 \leq \mathrm{dbh}<40 \mathrm{~cm}$ ( 5 of A. leiocarpa, 11 of E. uncinatum, 4

116 of $H$. excelsum, and 121 of T. burserifolia).

117 The dbh data for each species were grouped into diametric classes of $10 \mathrm{~cm}$-range to fit 118 probability density functions (PDFs). Normal, Beta, Gamma, Log-Normal, Johnson's

119 SB, and Weibull with three parameters (Scolforo, 1998) PDFs were fitted. The diametric 120 structure of each species included the largest diameter class in which live individuals 121 were found in the $100 \%$ inventories. To avoid total numbers of individuals less than one 122 tree per ha per species (as occurred for A. leiocarpa and H. excelsum), the densities of 123 individuals were considered on a 10-ha scale (i.e. number of trees $10 \mathrm{ha}^{-1}$ ).

124 The goodness-of-fit tests of PDFs by species were performed in two steps, using the 125 Kolmogorov-Smirnov test $(\alpha=0.05)$. Initially, the goodness-of-fit of the theoretical 
126 PDFs to the empirical data was tested in each forest compartment. In the second stage,

127 the goodness-of-fit of the PDFs fitted to the data of the entire Sinop micro-region (i.e.,

128 for the total data set) were tested considering sample inventories and $100 \%$ inventories.

129 The best PDF for each species was selected based on the lowest maximum absolute

130 value between theoretical PDF and observed data ( $\mathrm{D}_{\text {calc. }}$ For Kolmogorov-Smirnov test)

131 and lowest error index (Reynolds et al., 1988).

\section{Modeling diametric growth by species}

133 Stem sections (discs) with approximately 5-cm thick were collected from trees from

134 different forests compartments in the Sinop micro-region. These samples were obtained

135 from the base of the first commercial log, approximately $1 \mathrm{~m}$ above the ground level, or

136 immediately above the sapopemas. We collected 9 discs samples from A. leiocarpa, 10

137 from E. uncinatum, 13 from $H$. excelsum, and 11 from $T$. burserifolia. The samples were

138 dried and polished and the growth rings were measured with an accuracy of $0.01 \mathrm{~mm}$ on

139 a LINTAB measurement table (Frank Rinn, Heidelberg, Germany), using the TSAP-

140 Win software (Rinn, 1996). Crossdating was carried out among radii of each tree and

141 among trees.

142 The mean increment and passage time were analyzed by dbh class. We adjusted the

143 growth models of Gompertz, Johnson-Schumacher, Lundqvist-Korf, Logistic,

144 Monomolecular, and Schumacher for each species (Burkhart; Tomé, 2012).

145 The values of the asymptotes $\left(\beta_{0}\right)$ were fixed at the upper limit of the largest diametric

146 class recorded in the $100 \%$ inventories used. To increase modeling accuracy, we used

147 the non-parametric Bootstrap method with 100 interactions (Miller, 2004), previously

148 used in studies of modeling growth in diameter (Brienen, 2005; Mattos et al., 2015;

149 Canetti et al., 2017). The models were fitted by non-linear regression using the PROC

150 NLMIXED procedure in the $\mathrm{SAS}^{\circledR}$ software. The most suitable growth model by 
151 species was selected based on the relative residual standard error $\left(\mathrm{S}_{\mathrm{yx} \%}\right)$, corrected

152 Akaike and Bayesian information criteria.

\section{Obtaining growth curves in individual volume for each species}

154 Initially, the commercial height at each diameter was obtained to estimate the

155 commercial volume at each age and to relate it to the diametric growth curve. The

156 commercial height/dbh ratio of 30 trees (randomly selected) per species was fitted by

157 non-linear regression (PROC NLMIXED procedure in the SAS ${ }^{\circledR}$ software) according to

158 equation 1 (Schöngart, 2008). Of the 30 trees, four came from sampling inventories (20

$159 \leq \mathrm{dbh}<40 \mathrm{~cm})$ and 26 from $100 \%$ inventories $(\mathrm{dbh} \geq 40 \mathrm{~cm})$. This selection method

160 was adopted due to the difference of inclusion levels among inventories and the varying

161 sizes of the measured areas.

162 To calculate the wood volume, we used commercial height and dbh for each age

163 (obtained from the diametric growth equation), and taper functions developed for the

164 municipality of Santa Carmem (MT) to calculate the wood volume. For E. uncinatum

165 and T. burserifolia, we used species-level taper functions (equations 2 and 3,

166 respectively) developed by Lanssanova (2012). For A. leiocarpa and H. excelsum we

167 used the general taper function for the municipality (equation 4) developed by

168 Lanssanova et al. (2018).

169 The $\mathrm{di} / \mathrm{dbh}$ ratio of the growth samples was applied to calculate the youngest diameters

170 at the $\mathrm{dbh}$, from which the volume at each age was calculated. As a result, the volume

171 growth curve of the individual tree was obtained for each species. From the volume

172 growth curves, the mean annual volume increment $\left(\mathrm{MAI}_{\mathrm{V}}\right)$ and current annual volume

173 increment $\left(\mathrm{CAI}_{\mathrm{v}}\right)$ curves for individual trees were obtained according to equations 5 and

1746.

$H=\frac{d b h \beta_{0}}{d b h+\beta_{1}}$ 


$$
\begin{aligned}
& {\frac{d_{i}}{d b h_{\text {E.uncinatum }}}}=1.20+2.97 \frac{h_{i}}{H}+10.95\left(\frac{h_{i}}{H}\right)^{2}+21.15\left(\frac{h_{i}}{H}\right)^{3}+19.51\left(\frac{h_{i}}{H}\right)^{4}+6.80\left(\frac{h_{i}}{H}\right)^{5} \\
& {\frac{d_{i}}{d b h_{\text {T.burserifolia }}}}^{4}=1.13+1.89 \frac{h_{i}}{H}+7.16\left(\frac{h_{i}}{H}\right)^{2}+14.02\left(\frac{h_{i}}{H}\right)^{3}+12.56\left(\frac{h_{i}}{H}\right)^{4}+4.15\left(\frac{h_{i}}{H}\right)^{5} \\
& \frac{d_{i}}{d b h_{\text {General }}}=1.21+2.94 \frac{h_{i}}{H}+10.94\left(\frac{h_{i}}{H}\right)^{2}+20.46\left(\frac{h_{i}}{H}\right)^{3}+17.93\left(\frac{h_{i}}{H}\right)^{4}+5.90\left(\frac{h_{i}}{H}\right)^{5} \\
& M A I_{v}=\frac{v_{t}}{t} \\
& C A I_{v}=v_{t+1}-v_{t}
\end{aligned}
$$

where: $\mathrm{dbh}=$ diameter at $1.30 \mathrm{~m}$ above ground level $(\mathrm{cm}) ; \mathrm{d}_{\mathrm{i}}=$ diameter at the sample collection height (disc sample, $\mathrm{cm}$ ); $\mathrm{h}_{\mathrm{i}}=$ height of sample collection (m); $\mathrm{H}=$ commercial height of the tree $(\mathrm{m}) ; \beta_{0}$ and $\beta_{1}$ $=$ model parameters fitted by non-linear regression; $\mathrm{MAI}_{\mathrm{v}}=$ mean annual volume increment $\left(\mathrm{m}^{3}\right) ; \mathrm{CAI}_{\mathrm{v}}=$ current annual volume increment $\left(\mathrm{m}^{3}\right) ; \mathrm{v}_{\mathrm{t}}=$ accumulated commercial volume $\left(\mathrm{m}^{3}\right)$, at different ages; $\mathrm{t}=$ age (years), according to the diametric growth curve.

181 The age of biological rotation of individual tree was obtained at the intersection point of

182 the $\mathrm{CAI}_{\mathrm{v}}$ and $\mathrm{MAI}_{\mathrm{v}}$ curves. If the age of biological rotation was not reached with the ages of the available samples, we extrapolated the growth equation in diameter to estimate that age. For the extrapolated diameters, the commercial volume and $\mathrm{CAI}_{\mathrm{v}}$ and $\mathrm{MAI}_{\mathrm{v}}$ were calculated, following the same procedures.

\section{Obtaining growth curves in volume of the population of each species}

187 To obtain growth in volume per unit area for the population of each species over time, individual growth curves in volume were associated with the PDFs. It was assumed that a species diametric distribution follows the same pattern that occurred in the past

190 (Gotelli, 2008; Lundqvist, 2017). From this premise, the maximization of the population

191 volume increments was obtained. The population was defined hereby as the number of 192 trees from the first to the last diametric class in which there were individuals alive until 193 the moment " $t$ ". 
194 The input of the PDFs is the dbh of the trees and the output is the estimated number of

195 trees per unit area. The growth equations developed to generate the diameter values

196 were used to estimate the number of trees alive at each time " $t$ ", considering the species'

197 growth curve. The procedure illustrated in Fig. 1 allowed us to estimate the population's

198 diametric evolution over time (time $\mathrm{x}$ number of trees $\mathrm{ha}^{-1}$ ). As the actual diametric

199 distributions were established with data from $\mathrm{dbh} \geq 20 \mathrm{~cm}$, the calculations were

200 performed from that diameter, according to the following procedure:

201 I. The number of trees at each time " $\mathrm{t}$ " (identified by the PDF) was multiplied by the volume of the individual tree $(\mathrm{v})$ at each time, resulting in the population production curve $(\mathrm{V})$ at each time referring to the species growth curve;

II. From the population volume production curve, $\mathrm{MAI}_{\mathrm{v}}$ and $\mathrm{CAI}_{\mathrm{v}}$ were derived (equations 5 and 6).

\begin{tabular}{|c|c|c|c|c|c|c|}
\hline & & & \multicolumn{2}{|c|}{ Obtained from: } & & \\
\hline Pdf & \multicolumn{2}{|c|}{$\begin{array}{c}\text { Dbh growth } \\
\text { equation }\end{array}$} & $\begin{array}{c}\text { Taper } \\
\text { equations }\end{array}$ & $\mathrm{Nx} \mathrm{v}$ & $\begin{array}{c}\text { Derivatives } \\
\text { of } \mathrm{V}\end{array}$ & ives \\
\hline $\begin{array}{c}\mathrm{N} \\
\text { (trees ha-1) }\end{array}$ & $\begin{array}{c}\text { Time } \\
\text { (years) }\end{array}$ & $\begin{array}{l}\text { Dbh } \\
(\mathrm{cm})\end{array}$ & $\begin{array}{c}\mathbf{v} \\
\left(\mathbf{m}^{3}\right)\end{array}$ & $\begin{array}{c}\text { V } \\
\left(\mathrm{m}^{3} \mathrm{ha}^{-1}\right)\end{array}$ & $\begin{array}{c}\text { MAIv } \\
\left(\mathrm{m}^{3} \text { ha }^{-1} \text { year }^{-1}\right)\end{array}$ & $\begin{array}{c}\text { CAIv } \\
\left(\mathrm{m}^{3} \text { ha }^{-1} \text { year }^{-1}\right)\end{array}$ \\
\hline 0.0955 & 70 & 27.8696 & 0.3783 & 0.0361 & $5.16 \times 10^{-4}$ & $1.86 \times 10^{-3}$ \\
\hline 0.0957 & 71 & 28.4297 & 0.3971 & 0.0380 & $5.35 \times 10^{-4}$ & $1.88 \times 10^{-3}$ \\
\hline 0.0958 & 72 & 28.9951 & 0.4166 & 0.0399 & $5.54 \times 10^{-4}$ & $1.91 \times 10^{-3}$ \\
\hline 0.0958 & 73 & 29.5656 & 0.4368 & 0.0419 & $5.73 \times 10^{-4}$ & $1.93 \times 10^{-3}$ \\
\hline 0.0957 & 74 & 30.1413 & 0.4577 & 0.0438 & $5.92 \times 10^{-4}$ & $1.95 \times 10^{-3}$ \\
\hline 0.0955 & 75 & 30.7221 & 0.4793 & 0.0458 & $6.10 \times 10^{-4}$ & $1.97 \times 10^{-3}$ \\
\hline
\end{tabular}

207 Fig. 1. Scheme showing the methodological process for obtaining the curves of volume increment of the population. The boxes with red outline inform the data source of the column to which the arrows are directed. PDFs = probability density functions; $\mathrm{N}=$ number of trees per hectare; $\mathrm{dbh}=$ diameter at $1.30 \mathrm{~m}$

210 above ground level; $\mathrm{v}=$ volume of individual tree; $\mathrm{V}=$ species population volume $\left(\mathrm{m}^{3} \mathrm{ha}^{-1}\right) ; \mathrm{MAI}_{\mathrm{v}}=$

211 mean annual volume increment; and $\mathrm{CAI}_{\mathrm{v}}=$ current annual volume increment.

212

\section{Management simulations}


214 The projection method by diametric class (Alder, 1995) was used to compare the

215 volumetric increments obtained from the different combinations of cutting cycle and

216 minimum cutting diameter (MCD), according to the following management scenarios:

217 I. $\mathrm{MCD}=50 \mathrm{~cm}$ and cutting cycle $=35$ years, according to current legislation

$218 \quad$ (Brasil, 2006);

219 II. MCD defined by the biological rotation age of the population (intersection of the $\mathrm{MAI}_{\mathrm{v}}$ and $\mathrm{CAI}_{\mathrm{v}}$ curves $)$ and cutting cycle $=35$ years;

III. MCD defined by the maximum $\mathrm{CAI}_{\mathrm{v}}$ and biological rotation age of the population and cutting cycle calculated using equation 7 (Schöngart, 2008).

Cutting cycle $($ years $)=\frac{\text { Age }_{\text {Max.CAIv }}}{0.1 d b h_{\text {Max.CAIV }}}$

where Cutting cycle (years) $=$ time interval between explorations in the forest (Schöngart, 2008); $\mathrm{dbh}_{\text {Max.CAIv }}=$ minimum cutting diameter, defined as the diameter at which the species reaches the maximum $\mathrm{CAI}_{\mathrm{v}} ; \mathrm{Age}_{\mathrm{Max} . \mathrm{CAIv}}=$ age at which the species reaches the MCD.

IV. MCD defined by dbh in which the maximum CAIv occurs at the individual tree level and cutting cycle calculated according to Schöngart (2008);

V. MCD defined by the dbh of biological rotation age of the population in volume and increasing cutting cycles (10 to 70 years).

232 The mathematical procedure for simulations in the projection method by diametric class 233 is presented in equation 8 (Alder, 1995).

$N_{k, t+1}=N_{k, t}+I_{k}-O_{k}-M_{k}-H_{k}$

234 where $\mathrm{N}_{\mathrm{k}, \mathrm{t}+1}=$ number of trees in dbh class $k$ in period $t+1 ; \mathrm{N}_{\mathrm{k}, \mathrm{t}}=$ number of trees in class $k$ in period $t ; \mathrm{I}_{\mathrm{k}}$

$235=$ ingrowth in class $k$ during the period; $\mathrm{O}_{\mathrm{k}}=$ number of trees passing from class $k$ to subsequent classes,

$236 \mathrm{M}_{\mathrm{k}}=$ mortality in class $k ; \mathrm{H}_{\mathrm{k}}=$ trees logged during the period. 
238 The matrices were built from the $30-\mathrm{cm}$ dbh class, for every 5 years $(\mathrm{t})$, until reaching

239 the desired cutting cycle. We considered the wood volume of trees with a dbh higher

240 than the MCD the volume to be harvested $\left(\mathrm{H}_{\mathrm{k}}\right)$. The following data were used:

241 I. Initial diametric structure $\left(\mathrm{N}_{\mathrm{k}, \mathrm{t}}\right)$ : obtained from PDFs fitted by species, $242 \quad$ considering $\mathrm{dbh} \geq 30 \mathrm{~cm}$;

243 II. Mean increment by diameter class (obtained from the growth equations). The number of trees passing to the subsequent classes $\left(\mathrm{O}_{\mathrm{k}}\right)$ was calculated from the passage time between diametric classes (equation 9), as described by Alder (1995).

$$
O_{k}=\frac{t . i}{w}
$$

where: $\mathrm{O}_{\mathrm{k}}=$ number of trees migrating from class $k$ to subsequent classes during the period considered; i

$249=$ mean increment $\left(\mathrm{cm} \mathrm{year}^{-1}\right)$ of the diametric class $k$ (obtained from the growth series); $\mathrm{w}=$ interval 250 between diametric classes $(10 \mathrm{~cm}$ in the present study); $\mathrm{t}=$ period considered.

III. Ingrowth $\left(\mathrm{I}_{\mathrm{k}}\right)$ : the number of trees in the $20-\mathrm{cm}$ diameter class (smallest dbh class obtained) was considered as ingrowth.

IV. Mortality $\left(\mathrm{M}_{\mathrm{i}}\right)$ : the mortality was estimated using equation 10 adapted from Lundqvist (2017).

$M_{i}=100\left(1-{\frac{N_{i+1} i_{i+1}}{N_{i} i_{i}}}^{\frac{2}{t_{i}+t_{i+1}}}\right)$

where: $\mathrm{M}_{\mathrm{i}}=$ percentage of annual mortality in diametric class $i ; \mathrm{N}_{\mathrm{i}}=$ number of trees in class $i ; \mathrm{N}_{\mathrm{i}+1}=$ number of trees in the class subsequent to $i ; \mathrm{i}_{\mathrm{i}}$ and $\mathrm{i}_{\mathrm{i}+1}=$ mean annual increment in diameter $(\mathrm{cm})$ of classes $i$ and $i+1$ (obtained from the growth equation); $\mathrm{t}_{\mathrm{i}}$ and $\mathrm{t}_{\mathrm{i}+1}=$ passage time (years) from the diametric classes $i$ and $i+1$ to the subsequent classes (obtained from the growth equation). 
261 After obtaining the final diametric structure of the projection matrix by diametric class,

262 the number of trees was converted into volume (applying the taper functions previously

263 described) to obtain the total wood production in the considered period. This production

264 was divided by the cutting cycles, in order to proportionally compare the production of

265 the tested MCD and cutting cycles.

267 Results

\section{Diametric structure}

269 When testing the adherence of general probability density functions (PDFs) adjusted to

270 the measured density distributions for each species and for each forest compartment, the

271 majority of tested PDF fitted (Table 1). The only exceptions found were the Normal

272 function (all areas) and the Beta function (areas 3, 4 and 6) for T. burserifolia.

274 Table 1. Goodness-of-fit test of the probability density function (PDF) fitted considering the total data set

275 to the observed diametric distributions in each study area by the Kolmogorov-Smirnov test.

\begin{tabular}{|c|c|c|c|c|c|c|c|c|c|}
\hline \multicolumn{2}{|c|}{ Species } & $\mathrm{D}$ & PDF & Area 1 & Area 2 & Area 3 & Area 4 & Area 5 & Area 6 \\
\hline \multirow{7}{*}{$\frac{\stackrel{\widetilde{\Xi}}{\mathbb{\Xi}}}{\stackrel{\mathbb{J}}{\mathbb{J}}}$} & \multirow{7}{*}{ 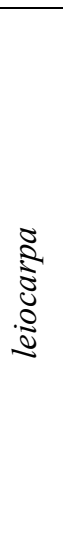 } & \multirow{7}{*}{  } & Normal & 0.048 & 0.100 & 0.078 & 0.139 & 0.089 & 0.063 \\
\hline & & & Beta & 0.047 & 0.094 & 0.081 & 0.141 & 0.092 & 0.062 \\
\hline & & & Gamma & 0.054 & 0.100 & 0.070 & 0.154 & 0.077 & 0.054 \\
\hline & & & Log Normal & 0.075 & 0.109 & 0.080 & 0.167 & 0.060 & 0.048 \\
\hline & & & Johnson's SB & 0.045 & 0.095 & 0.075 & 0.147 & 0.085 & 0.060 \\
\hline & & & Weibull 3p & 0.044 & 0.095 & 0.076 & 0.145 & 0.087 & 0.061 \\
\hline & & & $\mathrm{D}_{\text {tab. }}$ & 0.410 & 0.410 & 0.521 & 0.565 & 0.432 & 0.375 \\
\hline \multirow{4}{*}{  } & \multirow{4}{*}{ 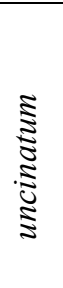 } & \multirow{4}{*}{$0^{\frac{\dot{v}}{\tilde{J}}}$} & Normal & 0.049 & 0.256 & 0.084 & 0.055 & 0.082 & 0.044 \\
\hline & & & Beta & 0.072 & 0.190 & 0.151 & 0.107 & 0.026 & 0.050 \\
\hline & & & Gamma & 0.069 & 0.261 & 0.081 & 0.045 & 0.099 & 0.060 \\
\hline & & & Log Normal & 0.095 & 0.278 & 0.063 & 0.068 & 0.122 & 0.085 \\
\hline
\end{tabular}




\begin{tabular}{|c|c|c|c|c|c|c|c|c|}
\hline & & Johnson's SB & 0.047 & 0.257 & 0.083 & 0.056 & 0.082 & 0.043 \\
\hline & & Weibull $3 p$ & 0.049 & 0.253 & 0.088 & 0.061 & 0.078 & 0.038 \\
\hline & & $\mathrm{D}_{\text {tab. }}$ & 0.189 & 0.294 & 0.240 & 0.240 & 0.270 & 0.270 \\
\hline \multirow{7}{*}{  } & \multirow{7}{*}{$\overbrace{}^{\frac{\dot{v}}{\tilde{J}}}$} & Normal & 0.124 & 0.124 & 0.124 & 0.124 & 0.151 & 0.124 \\
\hline & & Beta & 0.061 & 0.060 & 0.060 & 0.060 & 0.131 & 0.092 \\
\hline & & Gamma & 0.049 & 0.061 & 0.062 & 0.056 & 0.132 & 0.093 \\
\hline & & Log Normal & 0.051 & 0.068 & 0.065 & 0.068 & 0.132 & 0.093 \\
\hline & & Johnson's SB & 0.049 & 0.058 & 0.063 & 0.050 & 0.129 & 0.090 \\
\hline & & Weibull 3p & 0.038 & 0.051 & 0.067 & 0.054 & 0.125 & 0.086 \\
\hline & & $\mathrm{D}_{\text {tab. }}$ & 0.565 & 0.624 & 0.521 & 0.521 & 0.708 & 0.708 \\
\hline \multirow{7}{*}{ 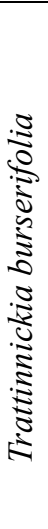 } & \multirow{6}{*}{$\rho^{\frac{\dot{j}}{\tilde{J}}}$} & Normal & $0.238^{*}$ & $0.238^{*}$ & $0.238 *$ & $0.238^{*}$ & $0.238^{*}$ & $0.238 *$ \\
\hline & & Beta & 0.187 & 0.170 & $0.170^{*}$ & $0.170^{*}$ & 0.170 & $0.170^{*}$ \\
\hline & & Gamma & 0.180 & 0.149 & 0.149 & 0.149 & 0.149 & 0.149 \\
\hline & & Log Normal & 0.167 & 0.119 & 0.106 & 0.106 & 0.106 & 0.106 \\
\hline & & Johnson's SB & 0.127 & 0.071 & 0.071 & 0.071 & 0.071 & 0.092 \\
\hline & & Weibull $3 p$ & 0.149 & 0.080 & 0.046 & 0.042 & 0.054 & 0.077 \\
\hline & & $\mathrm{D}_{\mathrm{t}}$ & 0.193 & 0.183 & 0.166 & 0.170 & 0.178 & 0.169 \\
\hline
\end{tabular}

Area $=$ sampled forest compartment; Dcalc. $=$ maximum absolute value between fitted PDF and observed

277 values in each compartment; Dtab. $=$ critical value of Kolmogorov-Smirnov test $(\alpha=0,05) ; *=$ the PDF

278 did not fit to the observed values (Dtab. $\leq$ Dcalc.).

279

280 When considering the adherence of all PDFs tested to the total set of observed data by

281 species all functions fitted. The Gamma function fitted better to the observed data for $A$.

282 leiocarpa, the Normal function for E. uncinatum and H. excelsum, and the Weibull with

283 three parameters for T. burserifolia (Fig. 2). A unimodal pattern was observed for the

284 diametric distributions of A. leiocarpa, E. uncinatum, and H. excelsum. On the other

285 hand, T. burserifolia decreased in a regular number of trees, similar to the negative 
286 exponential distribution. The decreased tendency starts in $H$. excelsum at $45-\mathrm{cm}$, in $A$.

287 leiocarpa at 55-cm, and in E. uncinatum at 75-cm diameter.

288

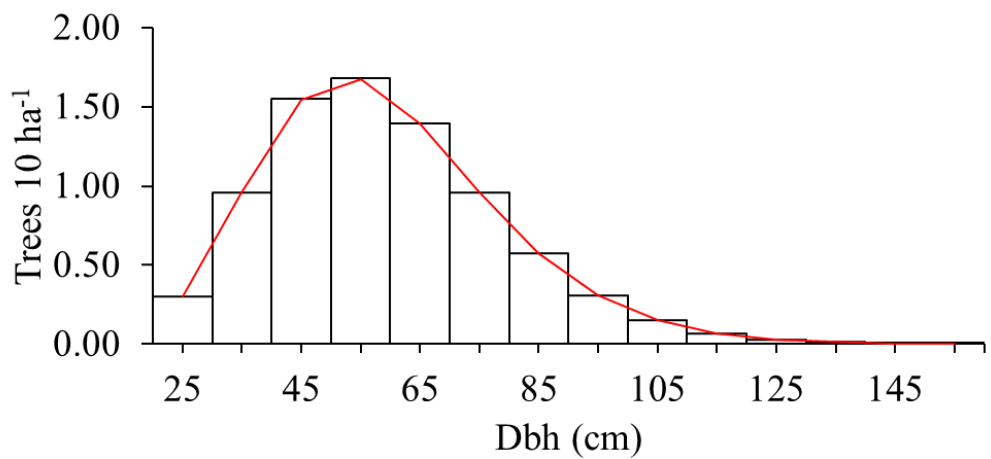

$f(d b h)=\frac{d b h^{8.883-1} e^{\frac{-d b h}{6.657}}}{6.657^{8.883} \Gamma(8.883)}$
$\mathrm{D}_{\text {calc. }}=0.003$
$\mathrm{RI}=0.025$

$\square$ Observed frequency - Gamma


290 Fig. 2. Probability density functions with better fitting for Apuleia leiocarpa (A), Erisma uncinatum (B),

291 Hymenolobium excelsum (C) and Trattinnickia burserifolia (D). Dbh = diameter at $1.30 \mathrm{~m}$ above ground 
292 level $(\mathrm{cm}) ; \Gamma=$ gamma function; Dcalc. $=$ maximum absolute value between fitted pdf and observed 293 values in each compartment; IR = error index (Reynolds et al., 1988).

\section{Height/dbh ratio}

296 The fitted height/dbh model showed satisfactory statistics and residual distribution for

297 all species (Fig. 3). The species that reached the highest commercial heights were $E$.

298 uncinatum and $H$. excelsum. The largest commercial height range occurred before

299 reaching $60-\mathrm{cm} \mathrm{dbh}$, ranging from 6.5 to $10.9 \mathrm{~m}$. After $60-\mathrm{cm} \mathrm{dbh}$, the commercial

300 heights tended to stabilize, ranging from 10.9 to $13.4 \mathrm{~m}$.

301

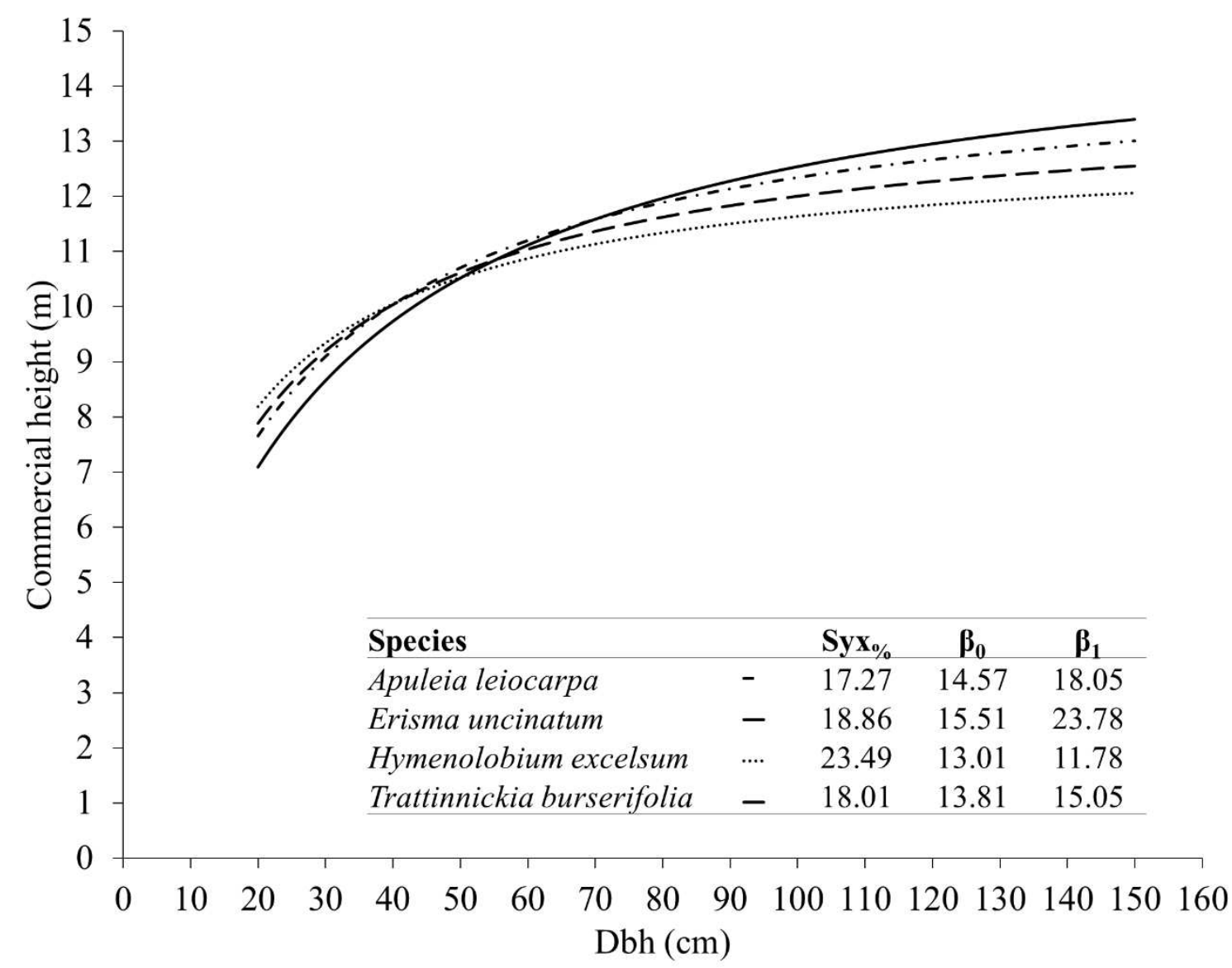

Fig. 3. Heigh/dbh models of Apuleia leiocarpa, Erisma uncinatum, Hymenolobium excelsum, and

304 Trattinnickia burserifolia. $\mathrm{dbh}=$ diameter at $1.30 \mathrm{~m}$ above ground level $(\mathrm{cm}) ; \beta_{0}$ and $\beta_{1}=$ equation parameters fitted by non-linear regression; $\mathrm{S}_{\mathrm{yx} \%}=$ relative residual standard error $(\%)$ 


\section{Diametric increment in dbh classes}

308 The mean increment by dbh class and passage time are shown in Fig. 4 and 5. Apuleia

309 leiocarpa presented an initial increase in dbh increment, and a decrease for the upper

310 diameter classes (Fig. 4A), characterizing the $U$ shape for the passage time (Fig. 5A).

311 Erisma uncinatum, H. excelsum, and T. burserifolia showed a higher increase in the

312 upper classes (Fig. 4 B, C and D), assuming a decreasing passage time (Fig. 5 B, C and 313 D).
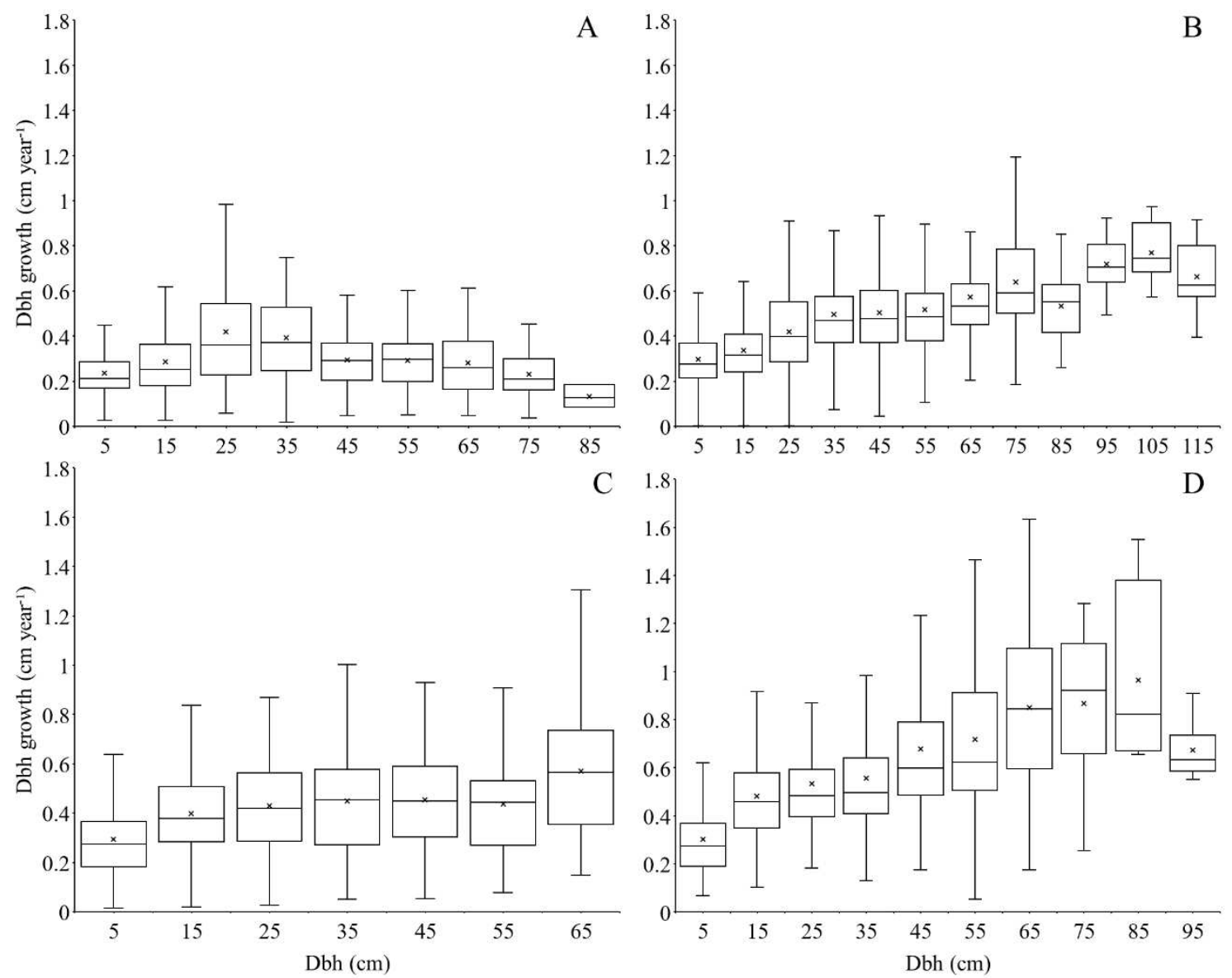

Fig. 4. Boxplot of the mean annual periodic increment by diameter class of Apuleia leiocarpa (A), Erisma uncinatum (B), Hymenolobium excelsum (C), and Trattinnickia burserifolia (D). Markers (x) represent the mean increment per diameter class, which were calculated only for the diameter classes with three or more trees. $\mathrm{Dbh}=$ diameter at $1.30 \mathrm{~m}$ above ground level. 

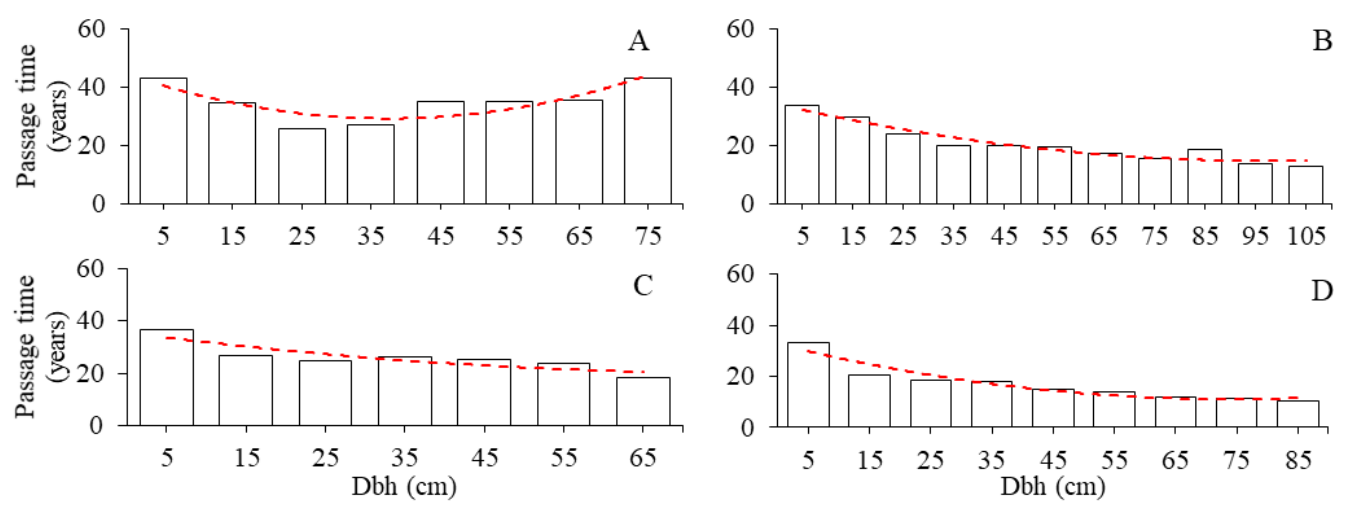

Fig. 5. Mean passage time by diameter class for Apuleia leiocarpa (A), Erisma uncinatum (B),

322 Hymenolobium excelsum (C), and Trattinnickia burserifolia (D) and their respective tendency lines. Only

323 passage times for diameter classes with three or more trees were considered. Dbh $=$ diameter at $1.30 \mathrm{~m}$

324 above ground level.

Modeling accumulated diameter growth and generating increment curves

327 The Johnson-Schumacher model better fitted the time series of A. leiocarpa and $H$.

328 excelsum, while the Gompertz was better for E. uncinatum and T. burserifolia. For

329 diameter growth, A. leiocarpa and $H$. excelsum reached the point of maximum tangency

330 close to $35 \mathrm{~cm}$ and $50 \mathrm{~cm}$, respectively, registering lower increments after these

331 diameter classes (Fig. $6 \mathrm{~A}$ and C). However, E. uncinatum and T. burserifolia did not

332 reach this point within the measured diameters (Fig. $6 \mathrm{~B}$ and D), showing upward

333 growth throughout the entire time series. 



C

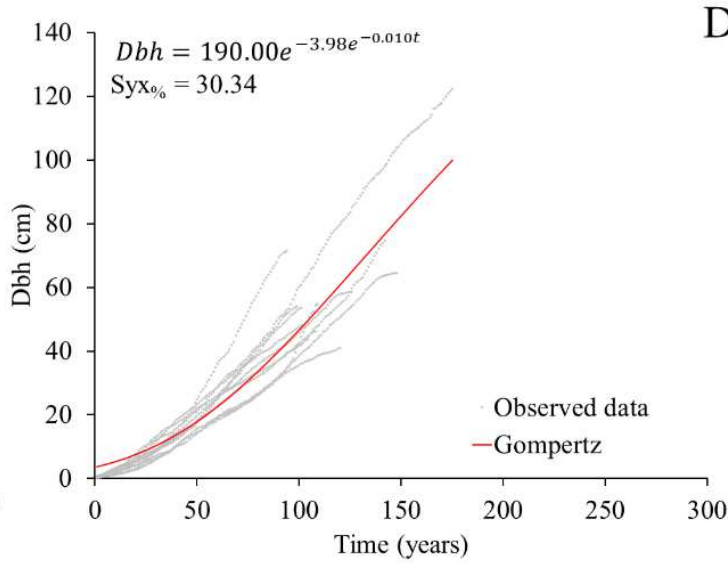

336 Fig. 6. Accumulated diametric growth equations fitted for Apuleia leiocarpa (A), Erisma uncinatum (B),

337 Hymenolobium excelsum (C), and Trattinnickia burserifolia (D). The growth equations were fitted for the 338 ages represented by three or more samples. Dbh $=$ diameter at $1.30 \mathrm{~m}$ above ground level; $\mathrm{t}=\mathrm{time}$ 339 (years); $\mathrm{S}_{\mathrm{yx} \%}=$ Relative Residual Standard Error $(\%)$.

341 Apuleia leiocarpa, E. uncinatum, and T. burserifolia reached the maximum current

342 annual increment in volume $\left(\mathrm{CAI}_{\mathrm{v}}\right)$ when considering the available data (Fig. $7 \mathrm{~A}, \mathrm{~B}$

343 and D). The maximum $\mathrm{CAI}_{\mathrm{v}}$ for $H$. excelsum was estimated at approximately 245 years

344 (Fig. 7C).

345 For the four species, the growth equation was used to estimate the biological rotation

346 age, which for individual trees occurred at the 95-cm dbh for A. leiocarpa, 121-cm for

$347 H$. excelsum, and $165-\mathrm{cm}$ for E. uncinatum and T. burserifolia. The maximum $\mathrm{CAI}_{\mathrm{v}}$ 
348 occurred close to the $60-\mathrm{cm}$ dbh for A. leiocarpa, 80-cm for H. excelsum, and $120-\mathrm{cm}$

349 for E. uncinatum and T. burserifolia (Table 2).

350

351 Table 2. Estimated ages and diameters on the biological rotation and the maximum current annual 352 increment of individual tree volume for the species.

\begin{tabular}{lllll}
\hline \multirow{2}{*}{ Species } & \multicolumn{2}{l}{ Biological rotation } & Maximum CAI & \\
\cline { 2 - 5 } & Dbh $(\mathrm{cm})$ & Age (years) & Dbh $(\mathrm{cm})$ & Age (years) \\
\hline Apuleia leiocarpa & 95 & 455 & 63 & 231 \\
Erisma uncinatum & 165 & 409 & 119 & 257 \\
Hymenolobium excelsum & 121 & 480 & 80 & 245 \\
\hline Trattinnickia burserifolia & 165 & 319 & 118 & 203
\end{tabular}

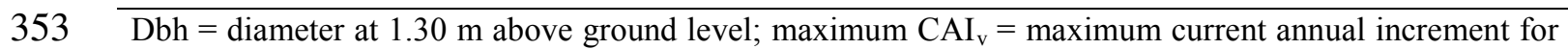

354 individual tree volume; Biological rotation = intersection of the $\mathrm{CAI}_{\mathrm{v}}$ and $\mathrm{MAI}_{\mathrm{v}}$ (current and mean annual

355 increment for individual tree volume) curves. 



357 Fig. 7. Volumetric increment curves (black) and dbh growth equation (red) for Apuleia leiocarpa (A),

358 Erisma uncinatum (B), Hymenolobium excelsum (C), and Trattinnickia burserifolia (D). In the primary y359 axis: $\mathrm{MAI}_{\mathrm{v}}=$ mean annual volumetric increment; $\mathrm{CAI}_{\mathrm{v}}=$ current annual volumetric increment. On the

360 secondary y-axis: $\mathrm{dbh}=$ diameter at $1.30 \mathrm{~m}$ above ground level $(\mathrm{cm})$ (growth equation fitted within the 361 measured data range); Edbh = accumulated diameter at $1.30 \mathrm{~m}$ above ground level (growth equation 362 outside the measured data range). 
364 The maximum $\mathrm{CAI}_{\mathrm{v}}$ and biological rotation ages of the population volume (Table 3;

365 Fig. 8) occurred in lower diameters than those recorded for individual trees (Fig. 7;

366 Table 2). Those ages were reached for diameters within the stem samples. There was

367 therefore no need for the extrapolation of the volume growth equations that was

368 required for the individual diameter growth (Fig. 7).

369

370 Table 3. Estimated ages and diameters on the biological rotation and the maximum current annual 371 increment by species population.

\begin{tabular}{lllll}
\hline \multirow{2}{*}{ Species } & \multicolumn{2}{l}{ Biological rotation } & Max. $\mathrm{CAI}_{\mathrm{v}}$ & \\
\cline { 2 - 5 } & Dbh (cm) & Age (years) & Dbh (cm) & Age (years) \\
\hline Apuleia leiocarpa & 58 & 203 & 44 & 160 \\
Erisma uncinatum & 86 & 192 & 64 & 154 \\
Hymenolobium excelsum & 52 & 150 & 37 & 106 \\
\hline Trattinnickia burserifolia & 58 & 116 & 34 & 80
\end{tabular}

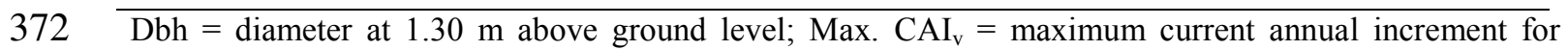

373 population volume; biological rotation = intersection of the curves of $\mathrm{CAI}_{\mathrm{v}}$ and mean annual increment in 374 volume for individual tree. 

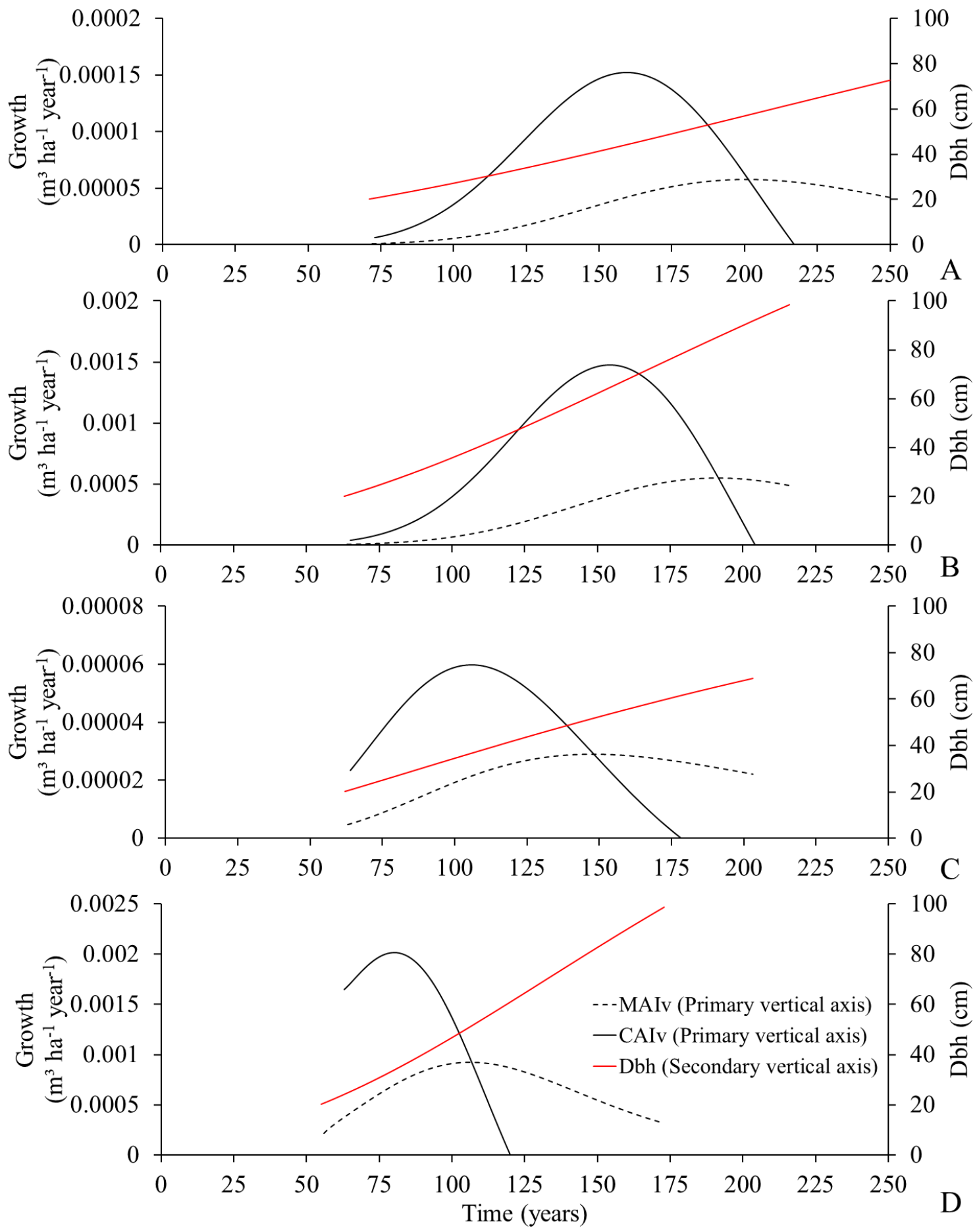

376 Fig. 8. Volumetric and diametric increment curves for the population of Apuleia leiocarpa (A), Erisma

377 uncinatum (B), Hymenolobium excelsum (C) and Trattinnickia burserifolia (D) (dbh $\geq 20 \mathrm{~cm})$. In the

378 primary y-axis: $\mathrm{MAI}_{\mathrm{v}}=$ mean annual increment in volume; $\mathrm{CAI}_{\mathrm{v}}=$ current annual increment in volume.

379 In the secondary y-axis: $\mathrm{dbh}=$ diameter at $1.30 \mathrm{~m}$ above ground level $(\mathrm{cm})$, obtained from the growth equation. 
383 The MCD criteria determined by the biological rotation age of the population and with

384 short cutting cycles (10 years) (Table 4) resulted in a higher annual volume yield for the

385 four species. For A. leiocarpa, H. excelsum and T. burserifolia, the maximum $\mathrm{CAI}_{\mathrm{v}}$ age

386 of the population and the cutting cycle, as suggested by Schöngart (2008), resulted in

387 the least increment $\left(\mathrm{m}^{3} \mathrm{ha}^{-1}\right.$ year $\left.{ }^{-1}\right)$ of all criteria. For E. uncinatum the management

388 criteria defined in the legislation resulted in the least increment.

389

390 Table 4. Simulation results using different criteria for defining the minimum cutting diameter and cutting

391 cycle.

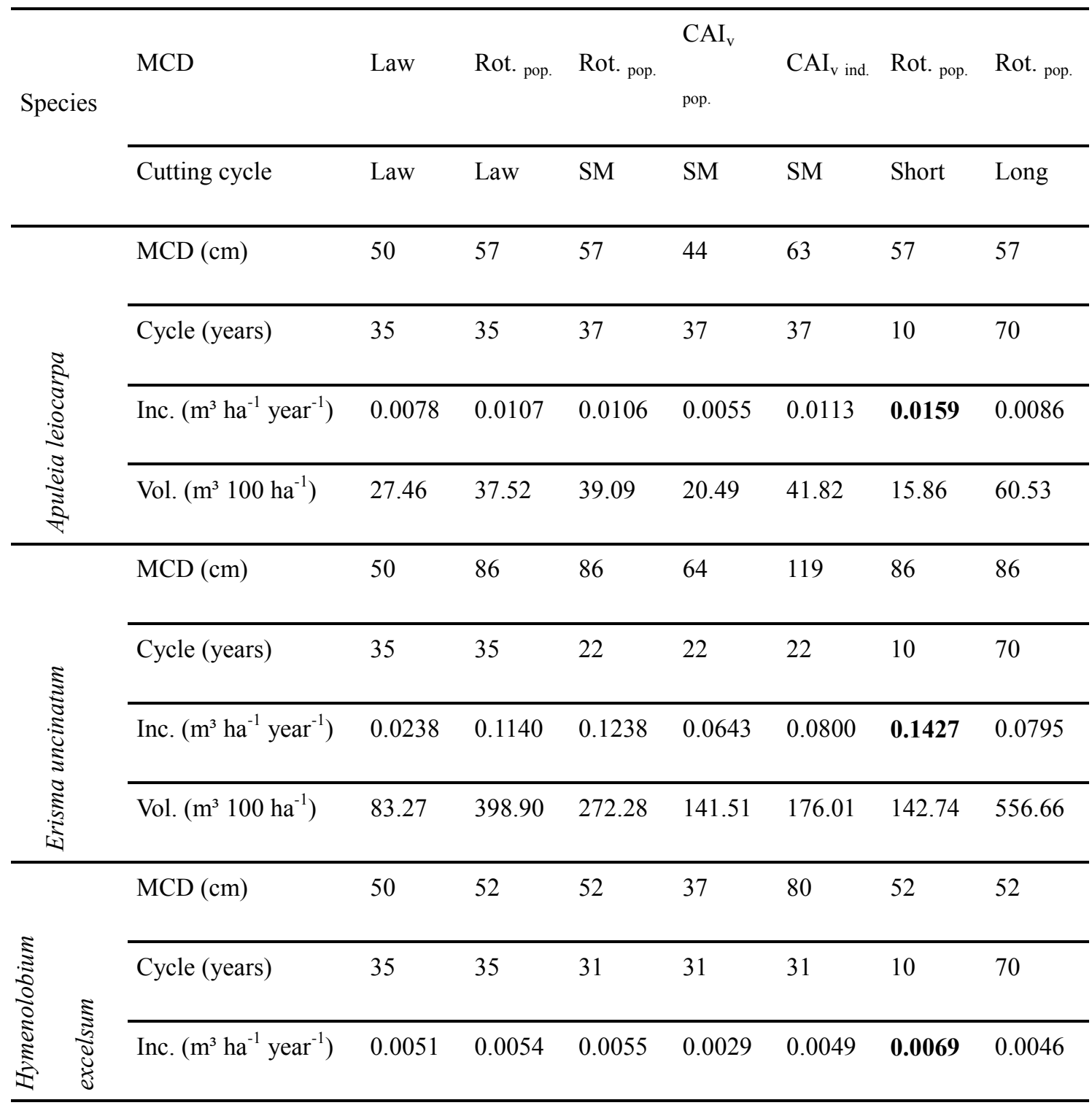




\begin{tabular}{|c|c|c|c|c|c|c|c|c|}
\hline & Vol. $\left(\mathrm{m}^{3} 100 \mathrm{ha}^{-1}\right)$ & 17.69 & 18.84 & 17.03 & 8.86 & 15.31 & 6.90 & 31.86 \\
\hline \multirow{4}{*}{ 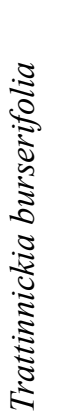 } & $\operatorname{MCD}(\mathrm{cm})$ & 50 & 58 & 58 & 34 & 118 & 58 & 58 \\
\hline & Cycle (years) & 35 & 35 & 17 & 17 & 17 & 10 & 70 \\
\hline & Inc. $\left(\mathrm{m}^{3} \mathrm{ha}^{-1}\right.$ year $\left.^{-1}\right)$ & 0.1511 & 0.2027 & 0.2776 & 0.1216 & 0.1966 & 0.3622 & 0.1384 \\
\hline & Vol. $\left(\mathrm{m}^{3} 100 \mathrm{ha}^{-1}\right)$ & 528.95 & 709.37 & 471.85 & 206.64 & 334.20 & 362.25 & 968.89 \\
\hline
\end{tabular}

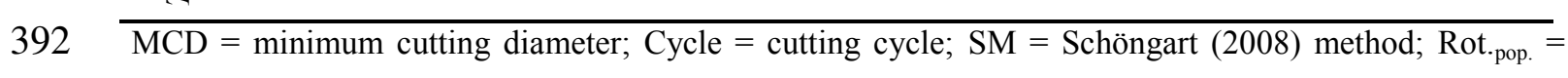

393 biological rotation age of the population; $\mathrm{CAI}_{\mathrm{v}}$ pop. $=$ maximum current annual increment of the

394 population; Legisl. = Normative Instruction parameters (Brasil, 2006); Inc. = simulated mean annual

395 volumetric increment; Vol. $\left(\mathrm{m}^{3} 100 \mathrm{ha}^{-1}\right)=$ total volume produced in a 100 -ha area, during the cutting

396 cycle length. The highest simulated annual increments in volume are presented in bold.

397

398 Considering the MCD defined by the population's biological rotation age, the annual

399 volumetric production decreased for the four species as the cutting cycle increased (Fig. 4009 9). 

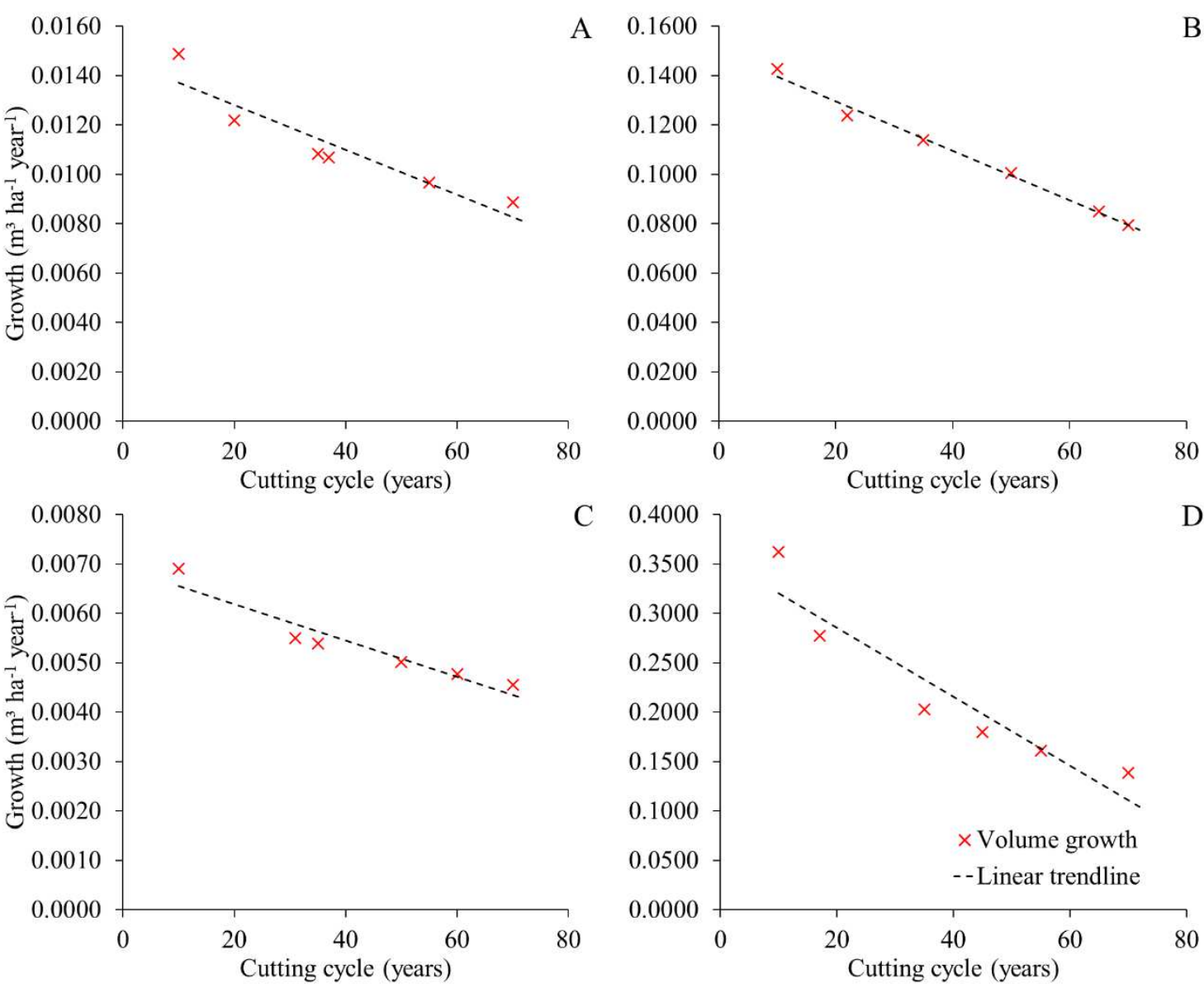

402 Fig. 9. Annual volume increment by the MCD defined by the population's biological rotation age and 403 different cutting cycles for Apuleia leiocarpa (A), Erisma uncinatum (B), Hymenolobium excelsum (C), 404 and Trattinnickia burserifolia (D).

405

\section{Discussion}

\section{Diametric distribution pattern of the species}

408 Most of the probability density functions (PDFs) (Table 1) fitted to data in each forest

409 compartment. Thus, a single PDF per species was fitted at the Sinop microregion (Fig.

410 2). Fitting only one PDF per species across the microregion suggests the existence of

411 similarities in the species diametric structure in the typology, contrasting to the claim

412 that ecosystems are chaotic and disordered (O'Hara, 2014). According to this same

413 author, ecosystems are not deterministic or ordered, due to the occurrence of repeated

414 disturbances on small scales, which prevent the forest from being homogeneous over 
415 time. However, for Larson (1992), the occurrence of environmental or anthropic

416 disturbances combined with the genetic variation of mixed forest does not imply that

417 forest development patterns cannot be discerned.

418 Also, the micro-region's pattern agrees with the demographic equilibrium theory, which

419 states that the diameter distribution balance may be scalar (Muller-Landau et al., 2006).

420 The forest structure is regulated by general principles of growth, mortality (Wang et al., 4212009 ) and ecological succession (Oliver, 1992).

422 Even in distant or geographically isolated regions, species with resembling 423 physiological and morphological characteristics can have a similar population structure 424 (Oliver, 1992). This occurs because the structures repeat over time in the forest (Gotelli, 425 2008). Diametric structure models allow us to infer the diameter in which tree number 426 reduces as a result of stagnant growth and increased mortality (Durrieu de Madron; 427 Forni, 1997; Braz et al., 2014).

428 Ecologists use the diametric structure to indicate the health of the forest. A high number 429 of smaller trees, as recorded for T. burserifolia (Fig. 2D), would represent forest 430 sustainability, since it would restore the upper classes (Kohyama, 1986; Muller-Landau 431 et al., 2006; Wang et al., 2009). These considerations originated from De Liocourt's 432 (1898) and Meyer's (1952) theories that state the concept of a balanced forest following 433 a negative exponential pattern.

434 However, several studies have found that some forest types and many individual species 435 may not follow such a negative exponential model (Condit et al., 1998; Dawkins; 436 Philip, 1998; Nyland, 2002; Pascal, 2003; Braz, 2010; Braz et al., 2014; Hossain et al., 437 2015), as occurred for three of the species in this study (Fig. 2 A, B and C).

438 A minor number of smaller trees, as recorded for A. leiocarpa, E. uncinatum and $H$. 439 excelsum, could indicate that the populations are declining (Condit, 1998; Hossain et al., 
2015). However, the forest diametric structure is not the only indicator defining

441 population maintenance. Schaaf et al. (2006) pointed out that the highest density does

442 not guarantee the species maintenance in the community, but their ability to compete

443 within the ecological niche does. The authors stated that if the species has few trees with

444 smaller diameters, but if the individuals tolerate competition for light in the lower

445 canopy, they can remain in the forest. Therefore, it is necessary to consider other

446 factors, particularly the species growth in the diameter classes (Condit et al., 1998).

447 Braz et al. (2014) identified over $60 \%$ of the basal area in the upper stratum in the Sinop

448 micro-region, a situation described by Pascal (2003). This author stated that the deficit

449 of trees in some dbh classes or the accumulation in larger dbh classes can result from

450 different causes. For example, a massive fruiting and germination due to favorable

451 climatic conditions can engender an overstock of trees in a particular dbh class. These

452 individuals can outgrow to larger dbh classes after a certain time, resulting in an

453 imbalanced diametric structure curve. These same individuals may be stagnated in a

454 certain dbh class when under the closed canopy of the forest.

455 An over-stocked upper stratum may have its regeneration constrained due to inadequate 456 access to light by trees in the lower canopy (Yegang; Jinxuan, 1988; Lamprecht, 1990; 457 Felfili, 1997; Nyland, 2002; Bettinger et al. 2009). In such cases, some species may 458 need a longer time scale to regenerate (Felfili, 1997). Over time, this factor de459 characterizes both the negative exponential structure (Braz, 2010; Bettinger et al., 2009)

460 and the whole forest increment (Dawkins; Philip, 1998).

\section{$461 \quad$ Production modeling at individual tree level}

462 Commercial height is an essential dendrometric variable for modeling production 463 forests since it is used for volume prediction (Lappi, 1997). Fitting parameters for the 464 commercial height/dbh ratio (Fig. 3) allows us to calculate commercial volumes of 
465 individual trees and stands more accurately where there is no field measuring. Other 466 authors used the commercial height/dbh ratio to model the wood volume in the Amazon 467 Forest (Brienen; Zuidema, 2006a; Fortini; Zarin, 2011; Miranda, Z. P. et al., 2018).

468 According to Alder (1995), in natural forests the initial growth of trees is slow, followed 469 by a phase of higher increments until it reaches its maximum. After that maximum 470 point, growth reduces until stagnation. Apuleia leiocarpa, E. uncinatum and T. 471 burserifolia followed this pattern (Fig. 4 A, B and D and 5 A, B and D), while $H$. 472 excelsum maintained constant growth during five diameter classes, not exceeding 0.5 $473 \mathrm{~cm}$ year ${ }^{-1}$, except in the 65 -cm class (Fig. 4C). The constant growth of H. excelsum until 474 larger sizes is a feature of late and emerging secondary species (Silva et al., 1985), 475 whose crowns extend above the canopy average level. These functional groups have 476 several micro-habitats during their ontogenesis (Clark; Clark, 1992). They are 477 characterized as partial sciophytes, shade-tolerate in the early development stages. 478 However, they require a high degree of illumination to overcome the intermediate stages 479 to maturity, increasing its growth during canopy opening (Maciel et al., 2017).

480 The decreasing tendency of passage time (Fig. $5 \mathrm{~B}, \mathrm{C}$, and D) for the late secondary 481 species (E. uncinatum, H. excelsum, and T. burserifolia) is also a feature of partial 482 sciophytes, that are shade tolerant, but do not demand shade for growth (Maciel et al., 483 2017).

484 The U-shaped passage time of the initial secondary species (A. leiocarpa) has already 485 been pointed out by Brienen and Zuidema (2006b) for Bertholletia excelsa Bonpl., an 486 initial secondary species (Gouveia et al., 2011). The same tendency was also registered 487 for Goupia glabra Aubl. in the micro-region of Sinop-MT (Oliveira et al., 2015), which 488 shows maximum growth in the $25-\mathrm{cm}$ and $35-\mathrm{cm}$ diameter classes, despite being a late 489 secondary species (Araújo et al., 2009), as occurred for A. leiocarpa (Fig. 5A). 
490 The biological rotation and maximum $\mathrm{CAI}_{\mathrm{v}}$ ages (Fig. 7; Table 2) were consistent with

491 the increment by diameter class (Fig. 4). Apuleia leiocarpa, an initial secondary species,

492 reached biological rotation and maximum $\mathrm{CAI}_{\mathrm{v}}$ ages in smaller diameters, while $H$.

493 excelsum reached it in intermediate sizes. The other two species achieved biological

494 rotation for an estimated dbh higher than $160 \mathrm{~cm}$. The maximum $\mathrm{CAI}_{\mathrm{v}}$ of an individual

495 tree were used in scientific studies to define minimum cutting diameters and cutting

496 cycles for species in Amazonas State (Schöngart, 2008; Rosa et al., 2017; Miranda D. L.

497 C., 2018), and has already been included in State forest law (Amazonas, 2010). If

498 logging happens before the maximum $\mathrm{CAI}_{\mathrm{v}}$ or after the maximum $\mathrm{MAI}_{\mathrm{v}}$, the volumetric

499 production will be inefficient. In this case, the species would not have reached or would

500 have passed their optimal growth (Schöngart, 2008; Braz; Mattos, 2015). Therefore,

501 knowing the maximum $\mathrm{CAI}_{\mathrm{v}}$ and $\mathrm{MAI}_{\mathrm{v}}$ per species is essential for sustainable forest

502 management in the Amazon forest.

503 The curves of individual wood volume increment indicate the ideal parameters for

504 sustainable management of each species. However, other variables representing the

505 species dynamics must be considered for decision-making. For example, it is essential

506 to define available stock of trees by diameter class and survival rates (Sebben et al.,

507 2008; Free et al., 2014; Groenendijk et al., 2017; Free, 2017).

\section{Volumetric population growth}

509 The maximum $\mathrm{CAI}_{\mathrm{v}}$ estimated from the population increment curves occurred for

510 diameters lower than $50 \mathrm{~cm}$ for A. leiocarpa, H. excelsum, and T. burserifolia, and at

511 64-cm diameter for E. uncinatum (Table 3; Fig. 8). The dbh when biological rotation

512 age occurs, at which $\mathrm{CAI}_{\mathrm{v}}$ and $\mathrm{MAI}_{\mathrm{v}}$ curves intersected, was around $50 \mathrm{~cm}$ for $A$.

513 leiocarpa, H. excelsum, and T. burserifolia, while for E. uncinatum this occurred at 86

514 cm. Erisma uncinatum has increased growth (Fig. 4) and a high concentration of trees in 
515 the upper diameter classes, which explains its yield culmination in larger dbh sizes. This

516 feature suggests the maintenance of larger dbh trees in the forest. In polycyclic

517 management systems, the trees available for logging must reach at least the diameters

518 with the highest growth potential in volume (Miranda, Z. P. et al., 2018) represented by

519 the MCD. For this reason, it is essential to determine the diameter that provides the

520 highest wood production for each species, based on the individual growth and the

521 population demographic characteristics.

522 According to Miranda, Z. P. et al. (2018), the species management in the mixed forest

523 should be carried out within the diameters of the higher $\mathrm{CAI}_{\mathrm{v}}$ and the biological rotation

524 of the population to maximize the volume. However, we observed a large range between

525 the maximum $\mathrm{CAI}_{\mathrm{v}}$ and the biological rotation ages, of at least 36 years and $14-\mathrm{cm} \mathrm{dbh}$

526 (Table 3; Fig. 8). It remains unclear which MCD should be applied the highest wood 527 yield for the next cutting cycle.

$528 \mathrm{The}_{\mathrm{CAI}} \mathrm{v}$ curves and biological rotation ages for all species population culminated in 529 lower diameters and ages compared to the increment curves at the individual level (Fig.

530 7; Table 2). The inclusion of the number of trees per diameter class anticipates the 531 culmination since it indirectly represents the population mortality and survival rates 532 (Assmann, 1970; Rubin et al., 2006). As trees increase in size, the number of trees decreases due to mortality, causing a deceleration in the gross wood production, even

534 though the remaining trees become larger (Seydack, 2000; Lundqvist, 2017). Therefore, 535 even if individual trees are growing, the total production per unit area will decline much 536 earlier (Assmann, 1970).

537 According to Seydack (2000) the population demographic factors of commercial species 538 are essential to determine the optimal parameters for forest management. In the natural 539 forest structure, the available stock of trees by diameter class is a crucial factor for yield 
540 projection in terms of the number of trees, basal area and volume (Ong; Kleine, 1996),

541 since they indicate survival by diameter class. The recovery time of the wood volume in

542 a post-intervention cycle is related to the species-specific growth, and also to the

543 number of trees in the smaller diameter classes to the intervention diameter (Brienen;

544 Zuidema, 2006a). Therefore, methods based on the inflection point age at the population

545 level are recognized for being more accurate in predicting maximum volume yield in a

546 natural forest than methods that consider only the individual tree growth.

547 Volumetric production using different management criteria

548 The increments $\left(\mathrm{m}^{3} \mathrm{ha}^{-1}\right.$ year $\left.{ }^{-1}\right)$ of each species were, in general, compatible with other

549 studies carried out in the Amazon, using permanent plots (Reis et al., 2010; Braz et al.,

550 2018). Reis et al. (2010) obtained similar increments for E. uncinatum (Table 4),

551 considering the cutting cycle and MCD of the Brazilian forest law (Brasil, 2006).

552 The cutting cycles and alternative MCD from those defined in Brazilian forest law

553 produced higher volumetric increment for the 4 studied species, similar to that obtained

554 by Groenendijk et al. (2017) in tropical rainforest in Cameroon. Erisma uncinatum

555 produced approximately seven times higher wood volume $\left(\mathrm{ha}^{-1}\right.$ year $\left.^{-1}\right)$ applying short

556 cutting cycle (10 years) and MCD 70\% larger $(86 \mathrm{~cm})$ than the Brazilian mandatory

557 MCD $(50 \mathrm{~cm})$. Erisma uncinatum presented the highest yield gain with the alternative

558 MCD and cutting cycles, due to the higher number of trees and growth in dbh classes

559 above $50 \mathrm{~cm}$ (Fig. 2 and 7). All results, especially those of E. uncinatum, showed the

560 potential of maximizing the forest management yield considering population

561 characteristics at the species level. The ideal MCD can increase volumetric increments,

562 even without silvicultural treatments, and so should be considered to increase

563 management productivity (Avila et al., 2017). 
564 The MCD defined by the dbh of the biological rotation of the population produced

565 higher annual increments for the four species, especially for shorter cutting cycles

566 (Table 4). It is important to consider the optimal population increment rate instead of

567 average growth data. This was previously considered by Ong and Kleine (1996) and

568 Bick et al. (1998) when studying natural forests in Malaysia. These authors obtained the

569 population growth from zero using permanent plots and simulations of forest production

570 and found the maximum sustainable yield population, defining optimum logging rates

571 and cutting cycles. Glauner et al. (2003) pointed out that the underlying principle of

572 management is to improve the forest condition, converting its stock to an optimum level

573 of increment of the commercial species.

574 In this study the dbh of the maximum $\mathrm{CAI}_{\mathrm{v}}$ (lowest among those tested as MCD)

575 produced the lowest volume increments considering the tested cycles (Table 4).

576 According to Bick et al. (1998), the harvested volume of two cycles must oscillate in the

577 population growth curve between a lower and an upper limit of the maximum yield

578 volume (i.e., the age of maximum $\mathrm{CAI}_{\mathrm{v}}$ ). These authors recommended an MCD above

579 the dbh of maximum $\mathrm{CAI}_{\mathrm{v}}$. Our results are consistent with these recommendations,

580 since the yield was higher when the logging was carried out at an age after the

581 maximum population $\mathrm{CAI}_{\mathrm{v}}$, such as the biological rotation age.

582 When considering only the individual tree growth curve to define the logging

583 parameters we observed that the MCD was always higher, although the volumetric

584 increments were lower, except for A. leiocarpa (Table 4). Contrary to the statement of

585 Sebbenn et al. (2008) and Lacerda et al. (2013), the excessive MCD increase does not 586 always imply higher forest productivity for all species. As mentioned, after reaching 587 their productivity peak the trees grow at moderate rates and the mortality is high. Slow 
588 growth trees should be logged before dying, through selective logging of mature trees of

589 declining vigor (Seydack, 2012; Lundqvist, 2017).

590 The cutting cycles must be long enough so that remaining trees reach the MCD

591 (Seydack et al., 1995). However, it cannot be too long, to ensure the trees' potential

592 growth and forest economic sustainability (Mattioli et al., 2015). The simulations

593 revealed that long cutting cycles resulted in smaller volumetric increments for all

594 species (Fig. 9), reaching a loss higher than 60\% compared to the 10 -year cutting cycle,

595 considering the same MCD (defined by population biological rotation). Therefore,

596 increasing the cutting cycle indefinitely (Sebbenn et al., 2008) represents a technical

597 error in a productive forest (Braz et al., 2015). Moreover, increasing the cut cycle

598 requires long-term investment (Glauner et al., 2003), which is difficult in unstable

599 political-economic environments (Groenendijk et al., 2017). On the other hand, short

600 cutting cycles require logging planning, following the reduced-impact logging

601 standards.

602 Suitable cutting cycles depend on economic considerations (Bick et al., 1998) besides

603 the MCD and the forest remaining structure. Economic analysis should support

604 selecting the best cutting cycle for each specific case, considering the optimal 605 parameters and exploitation feasibility for each species. Cost-benefit analyses can help

606 assess forest management's economic and social aspects (Rosa et al., 2017). Moreover,

607 higher MCD requires studies on tree health and risks of rot in older and bigger trees.

608

609 Conclusions

610 The diametric distribution of each species is similar throughout the transition zone

611 between open tropical rainforest and deciduous tropical rainforest in Brazilian Amazon.

612 Modifications of the standard diametric structure by species can be combined with 
613 growth models for inferring tropical forest dynamics, as done in this study. The

614 diametric distribution should support wood production planning and be the basis for

615 monitoring forest logging.

616 The optimum population minimum cutting diameter (MCD) of a species can

617 significantly increase the volumetric increment and the total wood volume, maximizing

618 the forest production under management. After determining the MCD, the best cutting

619 cycle must be defined according to economic analysis, which will specify the best 620 intervention time for the productive forest.

621 The methodology for species-level MCDs proved to be a useful tool and superior to the

622 fixed parameters defined in the Brazilian law or the methodologies that consider only

623 the individual tree growth. The procedure provides higher reliability for the maximized

624 wood production. The ideal MCDs based on dendrochronology substantially reduces 625 costs and time spent collecting data for forest modeling.

626

\section{Availability of data and materials}

628 The data that support the findings of this study are available from Embrapa Florestas

629 and Elabore Projetos e Consultoria Florestal but restrictions apply to the availability of

630 these data, which were used under license for the current study, and so are not publicly

631 available. Data are however available from the authors upon reasonable request and

632 with permission of Embrapa Florestas and Elabore Projetos e Consultoria Florestal.

633

634 Abbreviations

635 CAIv: current annual volume increment

636 DBH: diameter at $1.30 \mathrm{~m}$ above ground level

637 MAIv: mean annual volume increment 
638 MCD: minimum cutting diameter

639 PDF: probability density function

640

\section{Acknowledgements}

642 We are grateful to Elabore Projetos e Consultoria Florestal for providing inventory data

643 and discs samples and Simon Drew for the language editing.

644

645 Funding

646 This work was supported by Cipem (Center of Wood Producing and Exporting

647 Industries of Mato Grosso State), CAPES (Coordination for the Improvement of Higher

648 Education Personnel) and Embrapa Florestas (Brazilian Agricultural Research

649 Corporation).

650

651 Authors' contributions

652 AC participated of elaborating the paper conceptualization and methodology, made the

653 formal analysis and wrote the original draft of the paper.

654 EMB participated of elaborating the paper conceptualization and methodology,

655 collected field data and supervised the paper writing and design.

656 PPM participated of elaborating the paper conceptualization and methodology and

657 supervised the paper writing and design.

658 ROB participated of elaborating the paper conceptualization and collected field data.

659 AFF participated of elaborating the paper conceptualization and methodology and

660 supervised the paper writing and design.

661

662 Ethics approval and consent to participate 
663 Not applicable

664

665 Consent for publication

666 Not applicable

667

668 Competing interests

669 The authors declare that they have no competing interests.

670

671 References

672 Alder D (1995) Growth Modelling for Mixed Tropical Forest, 30th edn. ODA Forestry $673 \quad$ Research programme project R4676, Oxford

674 Alvares CA, Stape JL, Sentelhas PC, et al (2013) Köppen's climate classification map 675 for Brazil. Meteorol Zeitschrift 22:711-728. https://doi.org/10.1127/0941$676 \quad 2948 / 2013 / 0507$

677 Amazonas (2010) Instrução Normativa no 9, de 12 de novembro de 2010. Dispõe sobre 678 manejo florestal sustentável em áreas de várzea no Estado do Amazonas, e dá

679 outras providências. Diário Oficial do Estado do Amazonas, Brazil

680 Araujo R de A, Costa RB da, Felfili JM, et al (2009) Florística e estrutura de fragmento 681 florestal em área de transição na Amazônia Matogrossense no município de Sinop. 682 Acta Amaz 39:865-877. https://doi.org/10.1590/S0044-59672009000400015

683 Assmann E (1970) The principles of forest yield study. Pergamon Press Ltd. 
684 Avila AL, Schwartz G, Ruschel AR, et al (2017) Recruitment, growth and recovery of 685 commercial tree species over 30 years following logging and thinning in a tropical 686 rain forest. For Ecol Manage 385:225-235.

687 https://doi.org/10.1016/j.foreco.2016.11.039

688 Bailey RL, Dell R (1973) Quantifying Diameter Distributions with the Weibull

$689 \quad$ Function. For Sci 19:97-104

690 Bettinger P, Boston K, Siry J, Grebner D (2009) Forest Management and Planning. $691 \quad$ Academic Press, New York

692 Bick U, Droste H-J, Glauner R, Heuveldop JO (1998) Assessment and measurement of 693 forestry key parameters for the evaluation of tropical forest management. Plant Res 694 Dev 47/48:38-61

695

Brasil (2006) Instrução normativa n. 6 de 11 de dezembro de 2006. Diário Oficial da 696 União, Brasília, DF, 13 dez. 2006. Seção 1, p. 155

697

Braz EM, Mattos PP (2015) Manejo De Produção Em Florestas Naturais Da Amazônia: 698

699 Mitos E Verdades. Nativa 3:292-295. https://doi.org/10.14583/2318-

Braz EM (2010) Subsídios para o planejamento do manejo de florestas tropicais da amazônia. Universidade Federal de Santa Maria

Braz EM, Canetti A, Mattos PP, et al (2018) Alternative criteria to achieve sustainable 703 management of Mezilaurus itauba in the Brazilian Amazon. Pesqui Florest Bras 38:1-8. https://doi.org/10.4336/2018.pfb.38e201801648 
Braz EM, Mattos PP de, Oliveira MF, Basso RO (2014) Strategies for Achieving Sustainable Logging Rate in the Brazilian Amazon Forest. Open J For 04:100-105. https://doi.org/10.4236/ojf.2014.42015

708

709

710

711

712
Braz EM, Mattos PP, Thaines F, et al (2015) Criteria to be considered to achieve a sustainable second cycle in Amazon Forest. Pesqui Florest Bras 35:209. https://doi.org/10.4336/2015.pfb.35.83.941

Brienen RJW (2005) Tree rings in the tropics: a study on growth and ages of Bolivian rain forest trees

Brienen RJW, Zuidema PA (2006) The use of tree rings in tropical forest management : Projecting timber yields of four Bolivian tree species. For Ecol Manage 226:256267. https://doi.org/10.1016/j.foreco.2006.01.038

Brienen RJW, Zuidema PA (2006) Lifetime growth patterns and ages of Bolivian rain forest trees obtained by tree ring analysis. J Ecol 94:481-493. https://doi.org/10.1111/j.1365-2745.2005.01080.x

Burkhart HE, Tomé M (2012) Modeling Forest Trees and Stands. Springer Netherlands, Dordrecht

Canetti A, de Mattos PP, Braz EM, Netto SP (2017) Life pattern of urban trees: A growth-modelling approach. Urban Ecosyst 20:1057-1068

Carvalho PER (1981) Competição entre espécies florestais nativas em Irati - PR, cinco anos após o plantio. Bol Pesqui Florest 41-56 
725 Clark D a., Clark DB (1992) Life history diversity of canopy and emergent trees in a neotropical rain forestClark, D. A. ., \& .C. and D. B. (1992). Life history diversity of canopy and emergent trees in a neotropical rain forest. Ecological monographs, 62(3), 315-344. Retrieved from. Ecol Monogr 62:315-344.

729 https://doi.org/10.2307/2937114

730 Condit R, Sukumar R, Hubbell SSP, et al (1998) Predicting Population Trends from 731 Size Distributions : A Direct Test in a Tropical Tree Community. Am Nat 152:495-509. https://doi.org/10.1086/286186

733

Coomes DA, Duncan RP, Allen RB, Truscott J (2003) Disturbances prevent stem sizedensity distributions in natural forests from following scaling relationships. Ecol Lett 6:980-989. https://doi.org/10.1046/j.1461-0248.2003.00520.x

Dawkins HC, Philip MS (1998) Tropical Moist Forest Silviculture and Management: A History of Success and Failure. CAB International, Wallingford, UK

de Liocourt F (1898) De l'amenagement des sapinières. Bull Trimest 396-409

Dionisio LFS, Schwartz G, Lopes J do C, Oliveira F de A (2018) Growth, mortality, and recruitment of tree species in an Amazonian rainforest over 13 years of reduced impact logging. For Ecol Manage 430:150-156. https://doi.org/10.1016/j.foreco.2018.08.024

D’Oliveira MVN, Oliveira LC, Acuña MHA, Braz EM (2017) Twenty years monitoring growth dynamics of a logged tropical forest in Western Amazon. Pesqui Florest Bras 37:493-502. https://doi.org/10.4336/2017.pfb.37.92.1398 
Felfili JM (1997) Diameter and height distributions in a gallery forest tree community and some of its main species in central Brazil over a six-year period (1985-1991). Rev Bras Botânica 20:155-162. https://doi.org/10.1590/S010084041997000200006

Fortini LB, Zarin DJ (2011) Population dynamics and management of Amazon tidal floodplain forests: Links to the past, present and future. For Ecol Manage 261:551561. https://doi.org/10.1016/j.foreco.2010.11.007

Fortini LB, Cropper WP, Zarin DJ (2015) Modeling the complex impacts of timber harvests to find optimal management regimes for Amazon tidal floodplain forests. PLoS One 10:1-18. https://doi.org/10.1371/journal.pone.0136740

Free CM, Grogan J, Schulze MD, et al (2017) Current Brazilian forest management guidelines are unsustainable for Swietenia, Cedrela, Amburana, and Copaifera: A response to da Cunha and colleagues. For Ecol Manage 386:81-83. https://doi.org/10.1016/j.foreco.2016.09.031

Free CM, Matthew Landis R, Grogan J, et al (2014) Management implications of longterm tree growth and mortality rates: A modeling study of big-leaf mahogany (Swietenia macrophylla) in the Brazilian Amazon. For Ecol Manage 330:46-54. https://doi.org/10.1016/j.foreco.2014.05.057

Glauner R, Ditzer T, Huth A (2003) Growth and yield of tropical moist forest for forest planning: an inquiry through modeling. Can J For Res 33:521-535. https://doi.org/10.1136/bmj.2.2867.854 
767 Gotelli NJ (2008) A Primer of Ecology. Sinauer Associates Inc., Sunderland,

$768 \quad$ Massachusetts

769 Gouveia D, Soares M, Silva W, et al (2011) Avaliação do crescimento de espécies

770 florestais por grupo ecológico em áreas exploradas na FLONA do Tapajós. III

$771 \quad$ Encontro Amaz Agrárias 1-5

772 Groenendijk P, Bongers F, Zuidema PA (2017) Using tree-ring data to improve timber-

773

774 yield projections for African wet tropical forest tree species. For Ecol Manage 400:396-407. https://doi.org/10.1016/j.foreco.2017.05.054

775

776

777

778

779

780

781

782

783

784

785

786

787

788

Higuchi N (1996) Utilização e manejo dos recursos madeireiros das florestas tropicais úmidas. Acta Amaz 24:275-288

Hossain MA, Hossain MK, Alam MS, Uddin MM (2015) Composition and Diversity of Tree Species in Kamalachari Natural Forest of Chittagong South Forest Division, Bangladesh. J For Environ Sci 31:192-201. https://doi.org/10.7747/JFES.2015.31.3.192

IBGE - Instituto Brasileiro de Geografia e Estatística (1992) Mapa de vegetação do Brasil -Escala 1:5.000.000. http://www.dpi.inpe.br/Ambdata/mapa_sipam.php. Accessed 10 Mar 2017

IBGE - Instituto Brasileiro de Geografia e Estatística (2010) Censo Demográfico. https://censo2010.ibge.gov.br. Accessed 11 Nov 2017

Kohyama T (1986) Tree size structure of stands and each species in primary warmtemperate rain forests of Southern Japan. Bot Mag Tokyo 99:267-279. https://doi.org/10.1007/BF02489543 
Lacerda AEB, Nimmo ER, Sebbenn AM (2013) Demography of Hymenaea courbaril. For Sci 59:15-26

791

Lamprecht H (1990) Silvicultura nos tropicos: ecossistemas florestais e respectivas

792

793 especies arboreas - possibilidades e metodos de aproveitamento sustentado. GTZ, Eschborn

Lanssanova LR (2012) Ajuste De Funções De Afilamento Para Espécies Florestais Comerciais Do Bioma Amazônico Matogrossense. Universidade Federal do Mato Grosso - UFMT

797

798

799

800

801

802

803

804

Lanssanova LR, Silva FA da, Schons CT, Pereira ACDS (2018) Comparação Entre Diferentes Métodos Para Estimativa Volumétrica De Espécies Comerciais Da Amazônia. BIOFIX Sci J 3:109-115. https://doi.org/10.5380/biofix.v3i1.57489

\section{Lappi J (1997) A Longitudinal Analysis of Height / Diameter Curves HEIGHT PLAYS} TWO in modeling the growth. For Sci 43:555-570

Larson BC (1992) Pathways of development in mixed-species stands. In: Kelty MJ, Larson BC, Oliver CD (eds) The Ecology and Silviculture of Mixed-Species Forests. Springer, Dordrecht, Netherlands, pp 3-10

Lundqvist L (2017) Tamm Review: Selection system reduces long-term volume growth in Fennoscandic uneven-aged Norway spruce forests. For Ecol Manage 391:362375. https://doi.org/10.1016/j.foreco.2017.02.011

Maciel MDNM, Watzlawick LF, Schoeninger ER, Yamaji FM (2017) Classificação ecológica das espécies arbóreas. Rev Acadêmica Ciência Anim 1:69. https://doi.org/10.7213/cienciaanimal.v1i2.14922 
811 Madron LD De, Forni E (1997) Aménagement forestier dans 1'Est du Cameroun. Bois

812 Forêts des Trop 39-50. https://doi.org/https://agritrop.cirad.fr/389267

813 Mattioli W, Ferrari B, Giuliarelli D, et al (2015) Conversion of Mountain Beech

814 Coppices into High Forest: An Example for Ecological Intensification. Environ

815 Manage 56:1159-1169. https://doi.org/10.1007/s00267-015-0549-2

816 Mattos PP, Braz EM, Domene VD, et al (2015) Relação Clima-Crescimento De Árvores 817 De Mimosa Tenuiflora Em Floresta Tropical Seca Sazonal, Brazil. Cerne 21:141818 149. https://doi.org/10.1590/01047760201521011460

819 Meyer HA (1952) Balanced Growth, and Drain in Uneven-Aged Forests. J For

820 Miller DP (2004) Bootstrap 101: Obtain robust confidence intervals for any statistic. In: 821 Twenty-Ninth Annual SAS Users Group International Conference. SAS Institute, 822 Cary, NC, pp 193-29

823 Miranda DLC, Higuchi N, Trumbore SE, et al (2018) Using radiocarbon-calibrated 824 dendrochronology to improve tree-cutting cycle estimates for timber management 825 in southern Amazon forests. Trees - Struct Funct 32:587-602.

826 https://doi.org/10.1007/s00468-018-1658-3

827 Miranda ZP, Guedes MC, Rosa SA, Schöngart J (2018) Volume increment modeling 828 and subsidies for the management of the tree Mora paraensis (Ducke) Ducke based 829 on the study of growth rings. Trees - Struct Funct 32:277-286.

830 https://doi.org/10.1007/s00468-017-1630-7 
831 Muller-Landau HC, Condit RS, Harms KE, et al (2006) Comparing tropical forest tree

832 size distributions with the predictions of metabolic ecology and equilibrium

833 models. Ecol Lett 9:589-602. https://doi.org/10.1111/j.1461-0248.2006.00915.x

834 Nyland RD (2002) Silviculture: concepts and applications, 2nd edn. McGraw-Hill,

$835 \quad$ Boston, MA

836 Odum EP (1988) Ecologia, Guanabara. Rio de Janeiro, Brasil

837 O’Hara K (2014) Transformations to Multiaged Stand Structures. In: Multiaged

838 Silviculture: Managing for Complex Forest Stand Structures. Oxford University

$839 \quad$ Press, pp $1-15$

840 Oliveira MF, Braz EM, Mattos PP de, et al (2015) Padrão de crescimento e diâmetro

841 ótimo de corte de cupiúba na microrregião de Sinop, MT. Colombo, Brasil

842 Oliver CD (1992) Similarities of stand structures and stand development processes

843 throughout the world — some evidence and applications to silviculture through

844 adaptive management. In: Kelty MJ, Larson BC, Oliver CD (eds) The Ecology and

845 Silviculture of Mixed-Species Forests. Springer, Dordrecht, Dordrecht,

$846 \quad$ Netherlands, pp 11-26

847 Ong RC, Kleine M (1996) DIPSIM: Dipterocarp forest growth simulation model--a tool

848 for forest-level management planning. Dipterocarp For Ecosyst Sustain Manag

849 World Sci Singapore 228-246. https://doi.org/10.1017/CBO9781107415324.004

850 Orellana E, Figueiredo Filho A (2017) Uso do método da predição de parâmetros para

851 projetar a distribuição diamétrica em florestas nativas com a função Weibull.

$852 \quad$ Ciência Florest 27:981-991 
853 Pascal J (2003) Notions sur les structure et dynamique des forêts tropicales humides. Rev For Française 118. https://doi.org/10.4267/2042/5765

855

856

857

858

859

860

861

862

863

864

865

866

867

868

869

870

871

872

873

Reis LP, Ruschel AR, Coelho AA, et al (2010) Avaliação do potencial madeireiro na Floresta Nacional do Tapajós após 28 anos da exploração florestal. Pesqui Florest Bras 30:265-281. https://doi.org/10.4336/2010.pfb.30.64.265

Reynolds MR, Burk TE, Huang W-C (1988) Goodness-of-Fit Tests and Model Selection Procedures for Diameter Distribution Models. For Sci 34:373-399

Ribeiro ES, Paula MH De, Rossi R, et al (2016) Espécies florestais comercializadas pelo estado de mato grosso. Biodiversidade 15:2-20

Rinn F (1996) TSAP Win v. 3.6: Reference Manual: Computer Program for Tree-Ring Analysis and Presentation. RINNTECH, Heidelberg, Germany

Rosa SA, Barbosa ACMC, Junk WJ, et al (2017) Growth models based on tree-ring data for the Neotropical tree species Calophyllum brasiliense across different Brazilian wetlands: implications for conservation and management. Trees - Struct Funct 31:729-742. https://doi.org/10.1007/s00468-016-1503-5

Rubin BD, Manion PD, Faber-Langendoen D (2006) Diameter distributions and structural sustainability in forests. For Ecol Manage 222:427-438. https://doi.org/10.1016/j.foreco.2005.10.049

Schaaf LB, Figueiredo Filho A, Galvão F, Sanquetta CR (2006) Alteração na estrutura diamétrica de uma floresta ombrófila mista no período entre 1979 e 2000 . Rev Árvore 30:283-295. https://doi.org/10.1590/S0100-67622006000200016 
874 Schöngart J (2011) Amazonian Floodplain Forests. Springer Netherlands, Dordrecht

875 Schöngart J (2008) Growth-Oriented Logging (GOL): A new concept towards

876 sustainable forest management in Central Amazonian várzea floodplains. For Ecol

877 Manage 256:46-58. https://doi.org/10.1016/j.foreco.2008.03.037

878 Scolforo J (1998) Manejo florestal. Lavras: UFLA/FAEPE 1158-1170

879 Sebbenn AM, Degen B, Azevedo VCR, et al (2008) Modelling the long-term impacts of

880 selective logging on genetic diversity and demographic structure of four tropical

881 tree species in the Amazon forest. For Ecol Manage 254:335-349.

$882 \quad$ https://doi.org/10.1016/j.foreco.2007.08.009

883 Seydack AHW (2012) Regulation of Timber Yield Sustainability for Tropical and

884 Subtropical Moist Forests: Ecosilvicultural Paradigms and Economic Constraints.

885 In: Continuous Cover Forestry. Managing Forest Ecosystems. Springer, Dordrecht,

$886 \quad$ pp $129-165$

887 Seydack AHW (2000) Theory and Practice of Yield Regulation Systems for Sustainable 888 Management of Tropical and Subtropical Moist Natural Forests. In: von Gadow K, 889 Pukkala T, Tomé M (eds) Sustainable Forest Management. Springer Netherlands, $890 \quad$ Dordrecht, pp 257-318

891 Seydack AHW, Vermeulen WJ, Heyns HE, et al (1995) An unconventional approach to 892 timber yield regulation for multi-aged, multispecies forests. II. Application to a 893 South African forest. For Ecol Manage 77:155-168. https://doi.org/10.1016/0378$894 \quad 1127(95) 03578-X$ 
895 Silva JNM (1989) The behavior of the tropical rain forest of the Brazilian amazon after $896 \quad$ logging. Oxford University

897 Silva JNM (1997) Manejo de florestas de terra-firme da Amazônia Brasileira. In:

898 Tópicos em manejo florestal sustentável. Embrapa Florestas, Colombo, pp 59-96

899 Silva JNM, Carvalho JOP de, Lopes J do CA (1985) Inventário florestal de uma área

900 experimental na Floresta Nacional do Tapajós. Bol Pesqui Florest 38-110

901 SIVAM P (2002) Mapa de Vegetação da Amazônia Legal - RADAM/SIPAM. In:

902 DNPM, Ministério Minas e Energ.

903 http://www.dpi.inpe.br/Ambdata/mapa_sipam.php. Accessed 10 Mar 2018

904 van Gardingen PR, Valle D, Thompson I (2006) Evaluation of yield regulation options 905 for primary forest in Tapajós National Forest, Brazil. For Ecol Manage 231:184-

906 195. https://doi.org/10.1016/j.foreco.2006.05.047

907 Vanclay JK (1989) A growth model for north Queensland rainforests. For Ecol Manage $908 \quad$ 27:245-271. https://doi.org/10.1016/0378-1127(89)90110-2

909 Wang X, Hao Z, Zhang J, et al (2009) Tree size distributions in an old-growth

910 temperate forest. Oikos 118:25-36. https://doi.org/10.1111/j.1600-

$911 \quad$ 0706.2008.16598.x

912 Wright SJ, Muller-Landau HC, Condit R, Hubbell SP (2003) Shade tolerance, realized

913 vital rates, and size distributions of tropical trees. Ecology 84:3174-3185

914 Yegang W, Jinxuan H (1988) A Spectral Analysis of the Population Dynamics of

915 Korean Pine in the Mixed Broad-leaved Pinus koraiensis Forest. J Ecol 19-23 


\section{Figures}

Obtained from:

\begin{tabular}{|c|c|c|c|c|c|c|}
\hline Pdf & \multicolumn{2}{|c|}{$\begin{array}{l}\text { Dbh growth } \\
\text { equation }\end{array}$} & $\begin{array}{c}\text { Taper } \\
\text { equations }\end{array}$ & $\mathrm{Nx} \mathrm{v}$ & \multirow{2}{*}{\multicolumn{2}{|c|}{$\begin{array}{l}\text { Derivatives } \\
\text { of } \mathrm{V}\end{array}$}} \\
\hline 5 & & & 5 & 5 & & \\
\hline $\begin{array}{c}\mathrm{N} \\
\left(\text { trees ha-1) }^{-1}\right)\end{array}$ & $\begin{array}{c}\text { Time } \\
\text { (years) }\end{array}$ & $\begin{array}{l}\text { Dbh } \\
(\mathrm{cm})\end{array}$ & $\begin{array}{c}\mathbf{v} \\
\left(\mathbf{m}^{3}\right)\end{array}$ & $\begin{array}{c}\text { V } \\
\left(\mathrm{m}^{3} \mathrm{ha}^{-1}\right)\end{array}$ & $\begin{array}{c}\text { MAIv } \\
\left(\mathrm{m}^{3} \text { ha' }^{-1} \text { year }^{-1}\right)\end{array}$ & $\begin{array}{c}\text { CAIv } \\
\left(\mathrm{m}^{3} \text { ha-1 }^{-1} \text { year }^{-1}\right)\end{array}$ \\
\hline 0.0955 & 70 & 27.8696 & 0.3783 & 0.0361 & $5.16 \times 10^{-4}$ & $1.86 \times 10^{-3}$ \\
\hline 0.0957 & 71 & 28.4297 & 0.3971 & 0.0380 & $5.35 \times 10^{-4}$ & $1.88 \times 10^{-3}$ \\
\hline 0.0958 & 72 & 28.9951 & 0.4166 & 0.0399 & $5.54 \times 10^{-4}$ & $1.91 \times 10^{-3}$ \\
\hline 0.0958 & 73 & 29.5656 & 0.4368 & 0.0419 & $5.73 \times 10^{-4}$ & $1.93 \times 10^{-3}$ \\
\hline 0.0957 & 74 & 30.1413 & 0.4577 & 0.0438 & $5.92 \times 10^{-4}$ & $1.95 \times 10^{-3}$ \\
\hline 0.0955 & 75 & 30.7221 & 0.4793 & 0.0458 & $6.10 \times 10^{-4}$ & $1.97 \times 10^{-3}$ \\
\hline
\end{tabular}

\section{Figure 1}

Scheme showing the methodological process for obtaining the curves of volume increment of the population. The boxes with red outline inform the data source of the column to which the arrows are directed. PDFs = probability density functions; $\mathrm{N}=$ number of trees per hectare; $\mathrm{dbh}=$ diameter at $1.30 \mathrm{~m}$ above ground level; $v$ = volume of individual tree; $V=$ species population volume $\left(m^{3}\right.$ ha- 1$) ;$ MAlv = mean annual volume increment; and CAlv = current annual volume increment. 




$$
\begin{array}{r}
f(d b h)=\frac{d b h^{8.883-1} e^{\frac{-d b h}{6.657}}}{6.657^{8.883} \Gamma(8.883)} \\
\mathrm{D}_{\text {calc. }}=0.003 \\
\mathrm{RI}=0.025
\end{array}
$$

\section{$\square$ Observed frequency} - Gamma


\section{Figure 2}

Probability density functions with better fitting for Apuleia leiocarpa (A), Erisma uncinatum (B), Hymenolobium excelsum (C) and Trattinnickia burserifolia (D). Dbh = diameter at $1.30 \mathrm{~m}$ above ground level $(\mathrm{cm}) ; \Gamma$ = gamma function; Dcalc. = maximum absolute value between fitted pdf and observed values in each compartment; $I R=$ error index (Reynolds et al., 1988). 


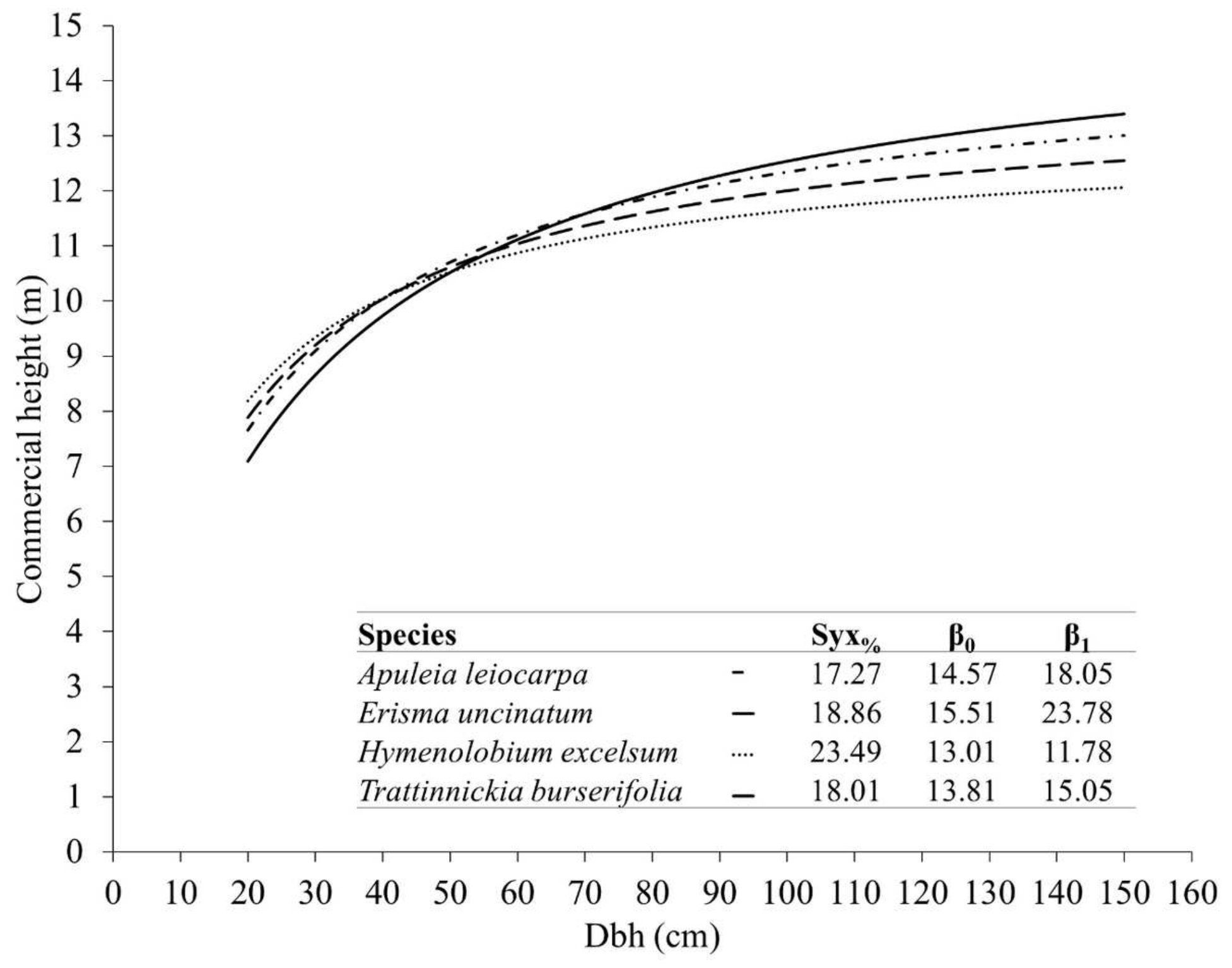

Figure 3

Heigh/dbh models of Apuleia leiocarpa, Erisma uncinatum, Hymenolobium excelsum, and Trattinnickia burserifolia. $\mathrm{dbh}=$ diameter at $1.30 \mathrm{~m}$ above ground level $(\mathrm{cm}) ; \beta 0$ and $\beta 1=$ equation parameters fitted by non-linear regression; Syx\% = relative residual standard error $(\%)$ 

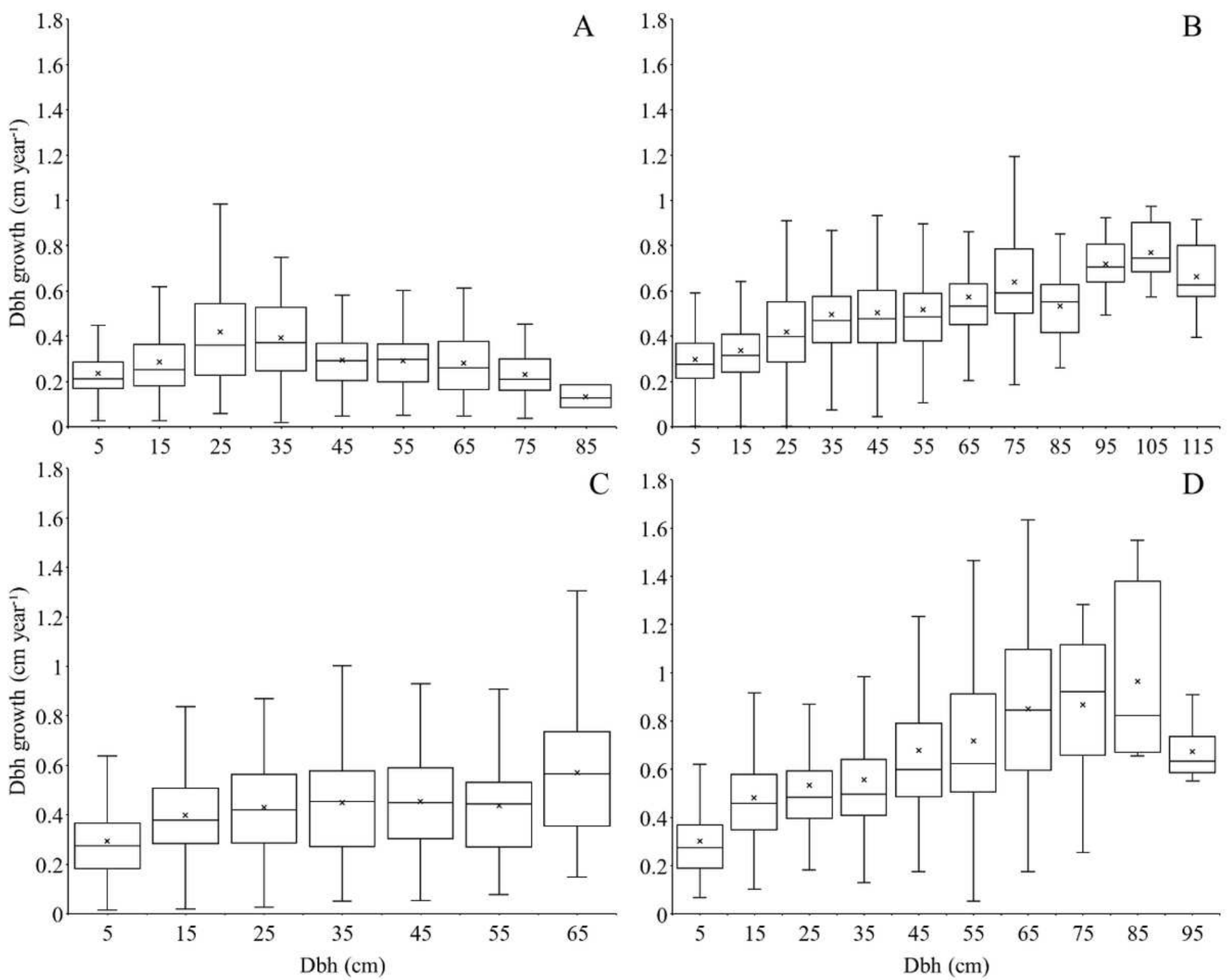

Figure 4

Boxplot of the mean annual periodic increment by diameter class of Apuleia leiocarpa (A), Erisma uncinatum (B), Hymenolobium excelsum (C), and Trattinnickia burserifolia (D). Markers ( $x$ ) represent the mean increment per diameter class, which were calculated only for the diameter classes with three or more trees. Dbh $=$ diameter at $1.30 \mathrm{~m}$ above ground level. 

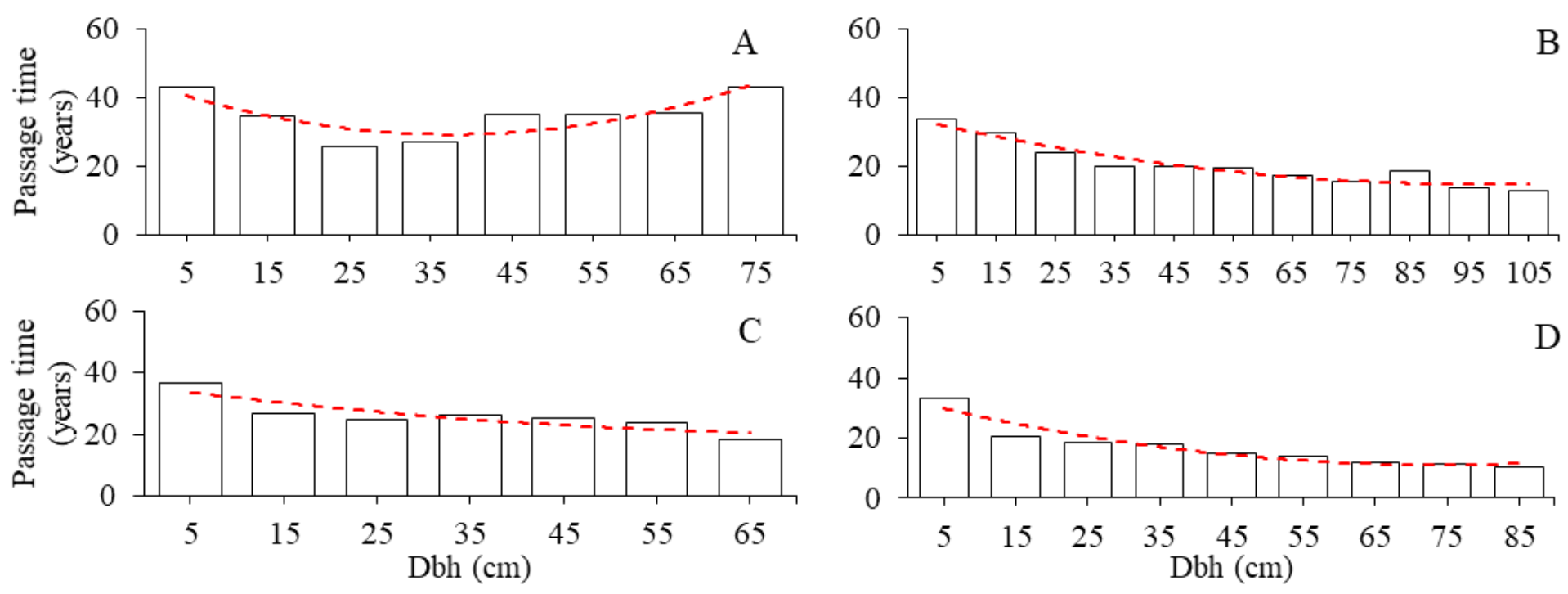

Figure 5

Mean passage time by diameter class for Apuleia leiocarpa (A), Erisma uncinatum (B), Hymenolobium excelsum (C), and Trattinnickia burserifolia (D) and their respective tendency lines. Only passage times for diameter classes with three or more trees were considered. $\mathrm{Dbh}=$ diameter at $1.30 \mathrm{~m}$ above ground level. 



Figure 6

Accumulated diametric growth equations fitted for Apuleia leiocarpa (A), Erisma uncinatum (B), Hymenolobium excelsum (C), and Trattinnickia burserifolia (D). The growth equations were fitted for the ages represented by three or more samples. $\mathrm{Dbh}=$ diameter at $1.30 \mathrm{~m}$ above ground level; $\mathrm{t}=$ time (years); Syx\% = Relative Residual Standard Error (\%). 

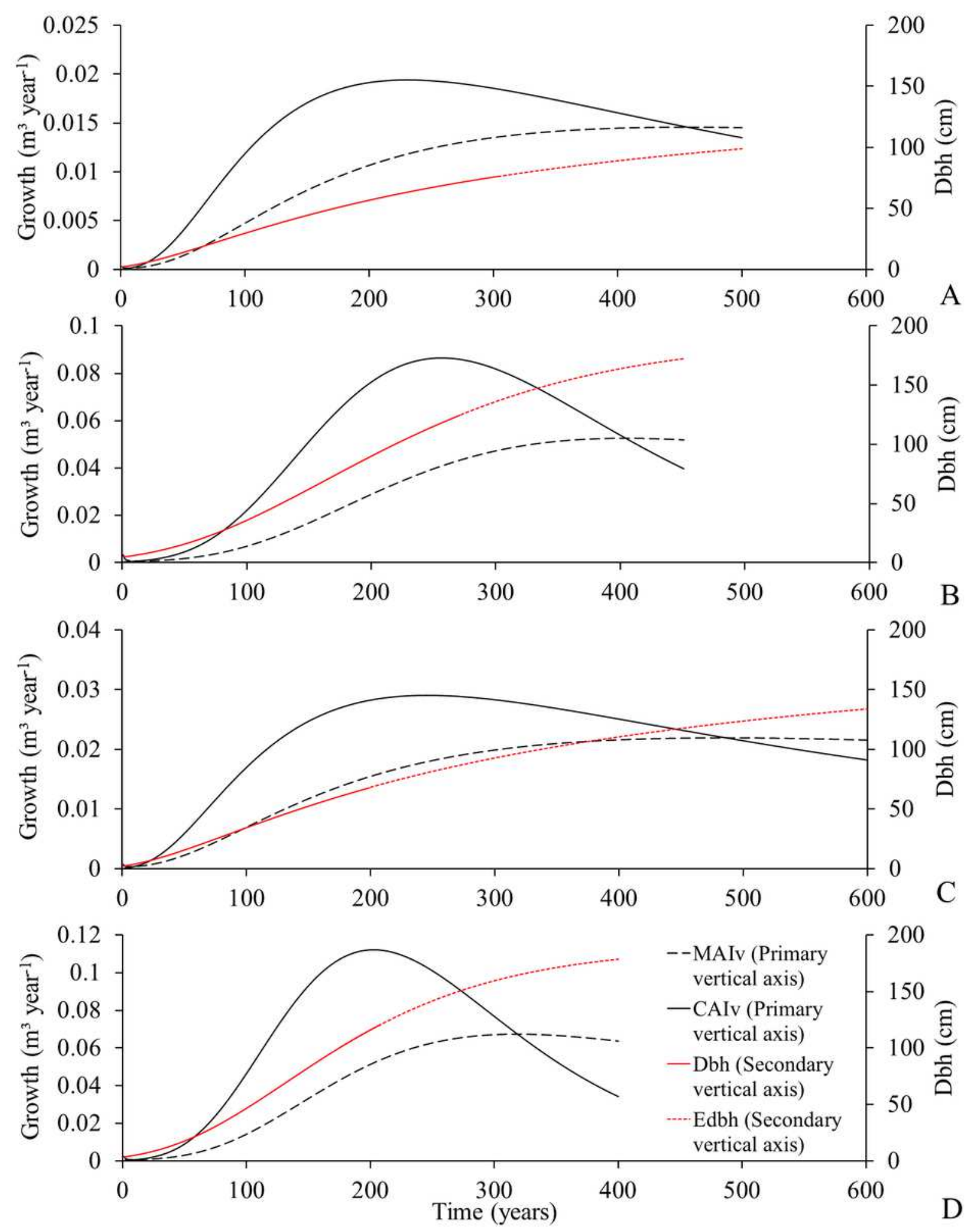

\section{Figure 7}

Volumetric increment curves (black) and dbh growth equation (red) for Apuleia leiocarpa (A), Erisma uncinatum (B), Hymenolobium excelsum (C), and Trattinnickia burserifolia (D). In the primary y-axis: MAlv = mean annual volumetric increment; CAlv = current annual volumetric increment. On the secondary yaxis: $\mathrm{dbh}=$ diameter at $1.30 \mathrm{~m}$ above ground level $(\mathrm{cm})$ (growth equation fitted within the measured data 
range); Edbh = accumulated diameter at $1.30 \mathrm{~m}$ above ground level (growth equation outside the measured data range).
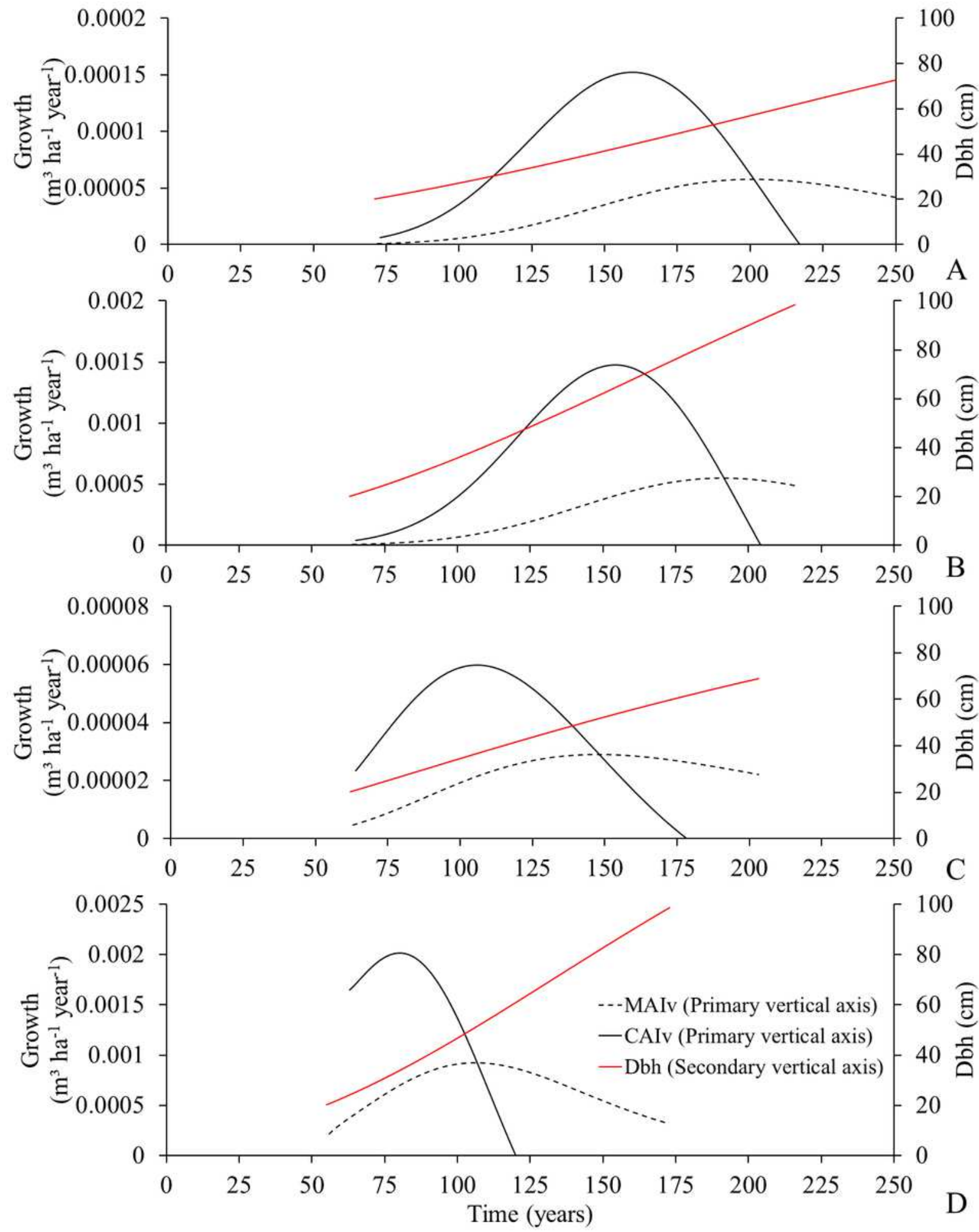

\section{Figure 8}

Volumetric and diametric increment curves for the population of Apuleia leiocarpa (A), Erisma uncinatum (B), Hymenolobium excelsum (C) and Trattinnickia burserifolia (D) $(\mathrm{dbh} \geq 20 \mathrm{~cm})$. In the primary y-axis: 
MAlv = mean annual increment in volume; CAlv = current annual increment in volume. In the secondary yaxis: $\mathrm{dbh}=$ diameter at $1.30 \mathrm{~m}$ above ground level $(\mathrm{cm})$, obtained from the growth equation.
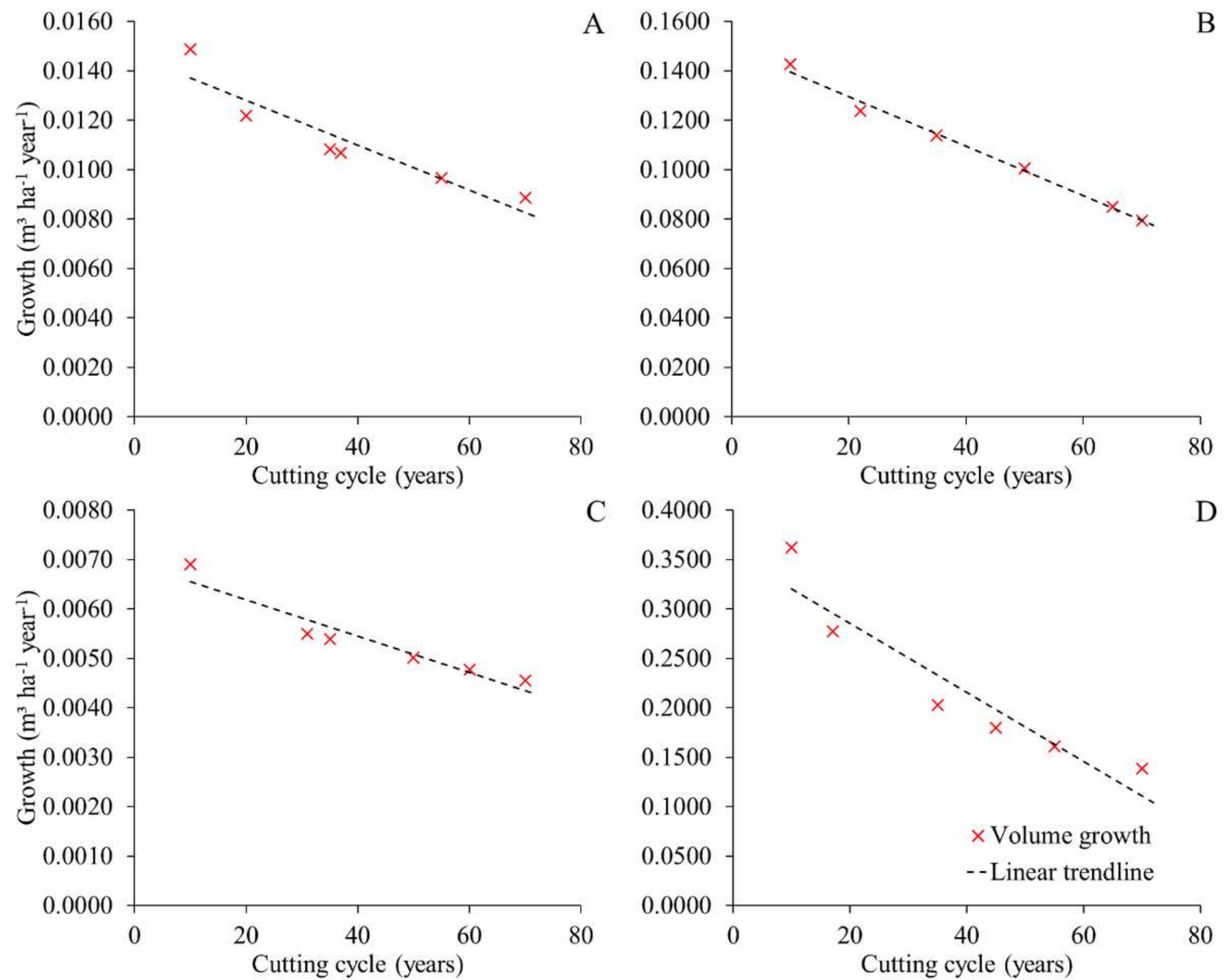

Figure 9

Annual volume increment by the MCD defined by the population's biological rotation age and different cutting cycles for Apuleia leiocarpa (A), Erisma uncinatum (B), Hymenolobium excelsum (C), and Trattinnickia burserifolia (D). 